\title{
Asymmetric Effects and the Herd Behavior in the Australian Equity Market
}

\author{
Mohammad Al-Shboul \\ Department of Accounting and Finance \\ College of Business Administration Economics \\ Al-Hussein Bin Talal University \\ P.O.Box (20), Ma'an, Jordan \\ Tel: 962-3-217-9000, Ext. 8344 E-mail: m.shboul@ahu.edu.jo
}

$\begin{array}{ll}\text { Received: November 29, } 2011 & \text { Accepted: December 20, } 2011 \quad \text { Published: April 1, } 2012 \\ \text { doi:10.5539/ijbm.v7n7p121 } & \text { URL: http://dx.doi.org/10.5539/ijbm.v7n7p121 }\end{array}$

\begin{abstract}
The purpose of this paper is to investigate whether Australian stock investors do herd. A sample of the largest 251 Australian listed firms is employed from the beginning of 2003 until the end of 2010 on daily and monthly basis. When the $\mathrm{CH}$ approach is used, no evidence of herd behavior for the daily and the monthly return series of AOI and S\&P300 indices is reported. However, the application of the CCK provides better results than those obtained by the cross-sectional stock price's model developed by $\mathrm{CH}$. According to $\mathrm{CCK}$, in normal conditions, the conditional CAPM specifies a linear relationship between CSAD and market returns. However, if herding occurs during periods of market stress, then a nonlinear relationship will also exist. To accommodate for the possibility that the degree of herding may be asymmetric in the up and the down markets, the CCK approach is applied by examining the nonlinear relationship between CSAD and market returns. Evidence of herding is found in the up and the down markets for both indices. This indicates that Australian investors exhibit asymmetric herding with respect to financial crisis, while they do not exhibit asymmetric herding in terms of fundamentals. Findings show evidence of herding asymmetry created by trading volume only in high volume state for both indices returns. However, in high volatility state, evidence of asymmetric herding is found for only the AOI monthly returns. This suggests that Australian investors remain in showing herding activities on daily and monthly basis and are affected by the decisions of investors in foreign markets of the US, the UK and China.
\end{abstract}

Keywords: Equity market, Herding, Market returns, Trading volume, Volatility, Financial crises

\section{Introduction}

The purpose of this paper is to investigate of whether Australian stock investors do herd. Research on the theory of finance has been developing since decades. One of the developments of the theory's literature is the inclusion of a new aspect to the literature which incorporates psychology (investors' behaviors) into finance and economics studies. The theory categorically recognizes the role of human behavior as the driving force behind price movements. One of the most important aspects of human behavior in financial markets is "herding". It is defined as a situation whereby a group of stock market investors intentionally follow the actions of other investors by trading in the same direction over a period of time (e.g. Demirer \& Kutan, 2006; Choi \& Sias, 2009). Proponents in the field of the stock herding behavior (see Thaler, 1999) attempted to explain how the stock market participants react to uncertainties, which could affect investment decisions, and in turn, would influence security price movements. Therefore, the call for the need to include human behavior factors such as herding in financial studies is obvious.

The investigation of the herd behavior in the Australian stock markets is of interest because of many motives. One of these motives is that the Australian equity market has been subject to rapid expansion and changes in regulatory and government policies (from coalition to labor in 2007). In addition, it has relatively large number of institutional versus individual investors which have increased rapidly over the recent years. Duong, Kalev and Krishnamurti (2009) stated that individual investors are an important investment group in Australia; with 55\% of the adult Australian population owning shares. In terms of market value, individual investors possess at least 
$22 \%$ of the Australian equity market and their trading activities account for about $51 \%$ of the market turnover as measured by the number of transactions (D'Aloisio, 2005). The Australian institutional investors have also enjoyed a continuous growth in the value of funds under management (Ali, Stapledon, \& Gold, 2003). For example, the total consolidated assets of managed funds institutions has risen from $\$ 1,010.2$ billion at the end of March 2006 to $\$ 1,410.5$ billion in the end of September 2011; an increase by $40 \%$ (Pink, 2011). These changes and expansions would have important effects on the behavior of Australian investors and finally on the stock market efficiency. It is also for such a market to be under examination as it provides an interesting setting for the analysis of herd behavior, especially during the period of the 2008 global financial crisis. This crisis causes a large deficit in the current account of Australia as it has been financing largely through overseas borrowings by local and foreign banks (Wettenhall, 2011). This deficit of course would finally affect the Australian economy growth rate. Lastly, the Australian stock markets are all characterized as one of the transparent and developed markets by Morgan Stanley Capital International (MSCI). Therefore, obtaining Australian data would produce well-trusted research.

Generally, the literature of herding behavior relies on the view that herding behavior is considered as a collective buying and selling actions of the individuals by following the performance of specific factors or styles such as the market portfolio, particular sectors, styles, macroeconomic signals (Chang, Cheng, \& Khorana, 2000; Hachicha, Bouri, \& Chakroun, 2007). Consequently, herding is identified by exploiting the information contained in the cross-sectional stock price movements. For example, Christie and Huang (1995) (hereafter CH) argued that herding, if present, would be stronger during extreme market conditions, leading to a reduction in the cross-sectional standard deviation of returns. A return on a particular asset would cluster around the market return and therefore the cross-sectional standard deviation of stock returns is more likely to decrease. $\mathrm{CH}$ found that herding in the U.S. equity market does not exist during periods of market stress. Following $\mathrm{CH}$, studies investigated herding behavior using data from developed stock markets (e.g. Chen, Wang, \& Lin, 2008; Demirer \& Kutan, 2006; Chiang \& Zheng, 2010). In addition, a nonlinear function of the relations between the cross-sectional absolute deviation of stock returns and market return was developed by Chang et al. (2000) (hereafter CCK). CCK allows testing for herding under the assumption that in periods of market stress the cross-sectional absolute deviation would increase at decreasing rate. CCK found that in the U.S. and Hong Kong markets no evidence of herding, whereas evidence of herding was found in South Korea, Taiwan and Japan. Studies followed CCK using developed countries data (Kim \& Wei, 2002; Gleason, Mathur, \& Peterson, 2004; Henker, Henker, \& Mitsios, 2006; Hachicha et al., 2007; Fu, 2010; Cajueiro \& Tabak, 2009; Zhou \& Lai, 2009; Chiang, Li, \& Tan, 2010).

The recent study by Henker et al. (2006) tested whether market wide and industry sector herding occurs daily and intraday in the Australian equity market. They used a sample of the 160 most actively traded stocks on the Australian stock exchange for the period $2001-2002$. They found that neither the entire market nor industry sector herding occurs intraday. However, herding was present for firm specific. Their study used the exact methodological specification of the $\mathrm{CH}$ and the $\mathrm{CCK}$ without including variables to test for the effects of financial crisis and fundamental factors on the tendency of herding. In addition, Henker et al. (2006), in their models, did not take into account the effects of investors in foreign markets on the herding Australia investors in their models. In this context, the current paper contributes to the literature in many ways. From methodological perspective, it incorporates the effects of the recent world changes such as the 2008 financial crisis on these herding approaches to capture the effects of the crisis on the high or low market returns. It includes a dummy variable to the CCK approach representing the effect of crisis period on the tendency of herding. It also investigates whether herding exhibits asymmetric effects associated with market returns, trading volume, and return volatility. Besides, the other contribution is the inclusion of firm specific fundamental factors to the CCK model to test for the effects of these factors on the existence of herding. In addition, changes in foreign markets such as Japan, China, the US, and the UK (the Australian mostly traded partners) may have an influence on the behavior of Australian investors and finally on the tendency of herding. Therefore, the study adds stock market returns of these foreign countries to the CCK model to test for the effect of investors in foreign markets on the Australian herding. Lastly, providing a new fresh evidence of herding in terms of the expansion and the rapid growth of the Australian economy (stock market) is another issue of investigation. Thus, the most recent time period, between 2003 and 2010, is used over monthly and daily stock basis using both the AOI and S\&P300 stock indices to provide such evidence.

Findings of this study, firstly, show absence of evidence of herding when the $\mathrm{CH}$ procedure is used. However, evidence is recorded for the presence of herding, for both daily and monthly basis of market indices, when using CCK. A negatively significant non-linear herding is found in periods of a rising market. Therefore, Australian 
investors tend to herd in the up and down markets. It is also reported that herding exhibits asymmetric effects during the financial crisis. This indicates that because of the influence of crisis, Australian investors cluster together for protection. However, no evidence of the effect of fundamental factors on herding is captured indicating that Australian investors do not rely on a specific factors or style. On daily basis of both stock indices, evidence of asymmetric herding with respect to trading volume is found only in high volume state, but for high and low volume states no evidence is captured. On monthly basis, evidence of herding asymmetric effects in terms of monthly AOI volatility is reported only in high volatility state. Yet, no effect of S\&P300 volatility on herding is captured in both high and low volatility states. Findings also indicate that, for daily and monthly data, Australian investors continue to herd and are affected by the decisions of foreign investors in the US, the UK and China.

The remainder of this paper is structured as follows. In section 2, a review of the literature on herding and its measurements are critically analyzed. Section 3 discusses the methodological approaches used and data description. The empirical results and data analyses are discussed in Section 4. Finally, Section 5 offers the conclusion.

\section{Literature Review}

A substantial effort has been devoted to investigate the issue of the herd behavior in financial markets and its measurements. The literature of herd behavior is evolved in different direction. Theoretically, researchers mostly focus their attention upon origins and causes of herding behavior among financial markets' investors, because it is difficult to specify a definition for herd behavior. Researchers always struggle to differentiate between herding in normal market conditions and herding in extreme market conditions. Therefore, two concepts were developed to explain the origins of herd behavior: rational and irrational. The rational concept suggests that investors adopt other investors' investment decisions to protect their own interests (Scharfstein \& Stein, 1990; Banerjee, 1992; Devenow \& Welsh, 1996). The irrational concept is different as investors blindly copy other's decisions, despite having their own information (Nofsinger \& Sias, 1999; Caparrelli, D'Arcangelis, \& Cassuto, 2004; Liao, Huang, $\& \mathrm{Wu}, 2011)$. Since the current study does not pay attention to investigate the origin of herding, this section focuses only on reviewing the literature related to the irrational concept.

Although theoretical models of the herd behavior have not been tested directly, the empirical literature has examined the presence of herding in a particular market, or among particular group of investors. For instance, Lakonishok, Shleifer, and Vishny (1992) (hereafter LSV) developed a special measure to detect herding among pension fund managers. They analyzed the correlation of trading patterns between group of investors with respect to buying or selling particular asset within the same period of time and they found that there is no trading convergence among pension fund managers. Empirical researches applied the LSV measure. A group of these researches reported strong evidence of herding through the correlation between stock returns and trading volume (e.g. Grinblatt, Titman, \& Wermers, 1995, Choi \& Sias, 2009; Jeon \& Moffett, 2010). However, in order to capture differences of traders behaviors, another group of researchers found weak evidence of herding for the correlation between individuals and aggregate stock returns and trading volume (e.g. Wermers, 1999; Hung, Lu, \& Lee, 2010; Venezia, Nashikkar, \& Shapira, 2011). A third group of studies investigated herding behavior among foreign investors on emerging markets and reported no evidence of herding (Walter \& Weber, 2006; Uchida \& Nakagawa, 2007; Barber, Terrance, \& Zhu, 2010). Even though these studies have a considerable contribution to the literature, it would lead to miss-measurement of herding as correlation of trading patterns between a group investors of buying and selling a particular asset are different among developed and developing countries.

The second recent measure of herding is generated by Christie and Huang (1995). CH was the first approach to detect whether herd behavior is present in the market-wide sense by employing the cross-sectional standard deviation of individual stock returns. According to $\mathrm{CH}$ in periods of extreme market movements, either significant increase or decrease of market returns, market participants tend to herd toward the market. As a result, a return on the particular asset would cluster around market return causing a decrease in the cross-sectional standard deviation (CSSD). Christie and Huang (1995) found that there is no significant herding in the U.S. markets, as securities return dispersion increases instead of decreasing during periods of large price movements. Empirical studies have applied the $\mathrm{CH}$ approach, but their results were mixed. A group of studies reported no evidence of the existence of herding. For example, Chang et al. (1999) displayed similar results to that of $\mathrm{CH}$ approach, namely there is no significant level of herding in the United States, Hong Kong and Japan. Caparrelli et al. (2004) also reported no evidence of herding so that herding is only present during extreme market conditions in the Italian stock market. Demirer and Kutan (2006) found no evidence of herding in the Chinese equity markets. Nevertheless, another group of studies reported evidence of the tendency of herd behavior. Chen 
et al. (2008) found evidence of herding in the Italian stock exchange in extreme market conditions, and before and during the 1999 crisis. Chiang and Zheng (2010) found evidence of herding in developed stock markets (except the US) and in Asian markets.

Although the $\mathrm{CH}$ approach has considerable contributions to herding literature, it might have some shortfalls. The first shortfall is associated with using the cross-sectional deviations of returns as a measure of herding. In this context, $\mathrm{CH}$ failed in the point that a decrease in cross-sectional standard deviation of returns does not necessarily imply the existence of herd behavior. Besides, $\mathrm{CH}$ model could be also criticized as it did not take into account the effect of changes in fundamental variables (see Shiller, 1989), so it did not distinguish between rational herding and irrational herding (Bikchandani \& Sharma, 2001). Another shortfall is that there is no such rule in which values of the market return must be considered as "extreme" because herd behavior is not necessarily observable only in periods of market stress. In contrast, herding might be observable in normal periods of the market. As a result, acknowledging that herding only exists in periods of market stress would lead to miss the main definition of herding. Therefore, the results reported by the $\mathrm{CH}$ approach and their empirical studies might be doubtful.

Chang et al. (2000) extended the approach of Christie and Huang (1995) by using a nonlinear function of the relations between cross-sectional absolute deviation of returns and market return. CCK model allowed for asymmetric effect of herding under the assumption that in periods of market stress cross-sectional absolute deviation of returns increases at decreasing rate. CCK argued that herding is present in South Korea and Taiwan, whereas no evidence of herding in the U.S, Hong Kong and Japan. Empirical studies applied the CCK model, but they did not report evidence of herding. Gleason et al. (2004) found no herd behavior among the sector ETFS using intraday data of the U.S. stock markets. Henker et al. (2006) reported no evidence of herding within market wide and industry sector using intraday and daily stock data frequencies. However, studies reported no evidence of herding. Fu (2010) found no evidence of herd behavior in Chinese stock markets demonstrating that the existence of asymmetric reaction as investors' tendency toward herding is higher in market downstream. Chiang et al. 2010 also reported no evidence of herding within both the Shanghai and Shenzhen B-share markets in the up markets only. However, evidence of detecting of herding is reported by another group of studies. Tan, Chiang, Mason, and Nelling (2008) suggested that herd behavior exists for both individual and institutional investors on the Shanghai and Shenzhen stock exchanges. Cajueiro and Tabak (2009) presented evidence of herd behavior for a large set of Japanese stocks and reported that herd behavior occurs in periods of extreme market movements. Zhou and Lai (2009) found that herding tends to be more prevalent with small stocks and in economic downturns and that investors are more likely to herd when selling rather than buying stocks.

\section{Methodology}

\subsection{The approach of Christie and Huang (1995) - CH}

$\mathrm{CH}$ developed an empirical measure to test whether herding can be identified using the Cross-sectional Standard Deviation between stock returns and market returns (CSSD). This measure focuses on approximating the average of individual stock returns to the market returns. CSSD measure is as follows:

$$
\operatorname{CSSD}_{t}=\sqrt{\frac{\sum_{i=1}^{N}\left(R_{i t}-R_{m t}\right)^{2}}{N-1}}
$$

where $R_{i t}$ represents the observed stock returns on sector $i$ at time $t, R_{m t}$ stands for the returns of the stock market index at time $\mathrm{t}, \mathrm{N}$ is the number of firms. This is based on the argument that security returns might not to diverge far from the overall market return when herding is present. Such idea can be found in some situations, such as an increase in dispersion of returns at a decreasing rate, or merely by a decrease in dispersion. $\mathrm{CH}$ rationalized that in period of market stress - which is characterized by high volatility -equity return dispersions are significantly lower than average because investors are more likely to restrain their own beliefs in favor of the market consensus. Following the $\mathrm{CH}$ approach, the following model is used to test for herding:

$$
\operatorname{CSSD}_{t}=\alpha_{0}+\beta_{1} D_{L t}+\beta_{2} D_{U t}+\varepsilon_{t}
$$

where $D_{\mathrm{Lt}}$ is a dummy variable, which equals to value of unity, if the market returns on time $t$ lies in the extreme lower tail of the distribution, or zero otherwise. $\mathrm{D}_{\mathrm{Ut}}$ is a dummy variable which equals to unity if market returns on time $t$ lies in the extreme upper tail of the distribution, or zero otherwise. The existence of herding occurs when the CSSD is low in periods of high price movements. This model contradicts the CAPM approach which predicts that, during market stress, large dispersions should be expected because individual stocks have different 
degree of sensitivities to the market returns. Nevertheless, herding is not implied by mere detection of low CSSD. If the estimated coefficients are negative and significant, it indicates evidence of herding.

\subsection{The approach of Chang et al. (2000) - CCK}

CCK generated an alternative method to test for herding by using the Cross-sectional Absolute Deviation of returns (CSAD). When deriving their model, Chang et al. (2000) attempted to take the rationale CAPM into account through rolling window regressions in estimating beta systematic of each firm for a period of time. $\beta_{\mathrm{it}}$ is the time-invariant systematic risk measure of the firm's $i$ at time t. $\beta_{\mathrm{mt}}$ is the systematic risk of each stock returns on the excess return of the market index which can be expressed as follow:

$$
\beta_{m t}=\frac{1}{N} \sum_{i=1}^{N} \beta_{i t}
$$

The expected cross-sectional absolute deviation of stock returns (CSAD) at time $t$ is defined as follows:

$$
C S A D_{t}=\frac{1}{N} \sum_{i=1}^{N}\left|\beta_{i t}-\beta_{m t}\right| \times E\left(R_{m t}-R_{f t}\right)
$$

where $E($.$) denotes the expected returns of firm's i$ at time $t, R_{m t}$ is the stock market returns at time $t, R_{f t}$ is the risk- free rate of interest at time t. To test for herding, a non-linear function between CSAD and market returns is implemented in Eq (5). Finance theory, through the conditional CAPM, states that under stock market normal conditions a linear relationship can apply between CSAD and market returns. However, during market stress, if herding is present, a non-linear relationship between CSAD and market returns may also exist. Hence, this nonlinear relationship can be given:

$$
C S A D_{t}=\delta_{0}+\delta_{1}\left|R_{m t}\right|+\delta_{2}\left(R_{m t}\right)^{2}+\varepsilon_{t}
$$

Chang et al. (2000) indicate that, it is adequate for a linear function to convert into a non-linear function, if there is an increased propensity on the part of market participants who intend to herd around the market consensus during periods of large price movements. A significantly negative coefficient, $\delta 2$, indicates the existence of herding behavior. As the market experiences large price swings, market participants tend to suppress their private information and tend to herd around the information emerging from the consensus of all market constituents. Stock returns under these conditions tend to converge, causing the return dispersion to either decrease or increase at a decreasing rate. In light of this, the present study measures the return dispersion by the CSAD in different way from that of the CCK because of two reasons. Firstly, this study does not rely on the accuracy of the specification of CAPM. It estimates betas of each stock without rolling windows regression (e.g. Christie \& Huang, 1995; Tan et al., 2008). Secondly, it is appropriate to indicate that, in practice, the length of time window used by CCK is questionable.

\subsection{Asymmetric effects of market return using the CCK approach}

Since the direction of market returns could affect investors' behaviors, the current study accommodates for the possibility that the degree of herding may be asymmetric in extreme market conditions (the market moves up and down). Following the CCK approach, two separate non-linear models are examined when the market moves up and/or down:

$$
\begin{aligned}
& C S A D_{t}=\delta_{0}+\delta_{1}^{U P}\left|R_{m t}^{U P}\right|+\delta_{2}^{U P}\left(R_{m t}^{U P}\right)^{2}+\varepsilon_{t} \\
& C S A D_{t}=\delta_{0}+\delta_{1}^{D N}\left|R_{m t}^{D N}\right|+\delta_{2}^{D N}\left(R_{m t}^{D N}\right)^{2}+\varepsilon_{t}
\end{aligned}
$$

where $R_{m t}{ }^{U P}$ and $R_{m t}{ }^{D N}$ are the market returns at time $\mathrm{t}$ when the market is trending up and down, respectively. CCK stated that market participants suppress their own predictions about asset prices during periods of large market movement, "especially" in the presence of moderate herding. They expected that return variations will "decrease (or increase at a decreasing rate) with an increase in the market return." In Eq. (6), negative and 
significant coefficients, $\delta_{I}^{U P}\left(\delta_{2}{ }^{U P}\right)$, indicate for the existence of linear (nonlinear) herding in the up market, while in Eq. (7) the coefficients $\delta_{1}{ }^{D N}\left(\delta_{2}{ }^{D N}\right)$ indicate for the existence of linear (nonlinear) herding in the down market.

\subsection{The asymmetric effect of financial crisis}

The possible effect of the 2008 financial crisis on investors' behaviors is also examined in this study. A dummy variable is added to the model in Eq. (7) to highlight the effect of the 2008 Global financial crisis in the following equation:

$$
C A S D_{t}=\gamma_{0}+\gamma_{1} R_{m t}+\gamma_{2}\left(R_{m t}\right)^{2}+\gamma_{3}\left(R_{m t}\right)^{2} * D_{t}+\varepsilon_{t}
$$

The dummy variable $\mathrm{D}_{t}$ takes value of unity during the 2008 global financial crisis from the mid of 2007 to the end of 2008 , or zero otherwise. It is expected that if $\gamma_{3}$ is significantly negative this crisis is more likely to have an impact on the detection of herding between the Australian stock investors.

$$
\begin{gathered}
C A S D_{t}=\gamma_{0}+\gamma_{1}\left|R_{m t}^{U P}\right|+\gamma_{2}\left(R_{m t}^{U P}\right)^{2}+\gamma_{3}\left(R_{m t}^{U P}\right)^{2} * D_{t}+\varepsilon_{t} \\
C A S D_{t}=\gamma_{0}+\gamma_{1}\left|R_{m t}^{D N}\right|+\gamma_{2}\left(R_{m t}^{D N}\right)^{2}+\gamma_{3}\left(R_{m t}^{D N}\right)^{2} * D_{t}+\varepsilon_{t}
\end{gathered}
$$

It follows that it is possible to test whether herding exhibits asymmetric effects in terms of the financial crisis in the up and the down market, as in Eqs (9 and 10). The same procedure of the dummy variable as above is used in this study to test for the possibility that the degree of herding may be asymmetrically affected by the financial crisis on herding asymmetry when the market goes up and down. If the coefficient, $\gamma_{3}$, is negatively significant in Eq. (9), this suggests that Australian investors would be affected by other investors' decisions with various levels of information which make their behavior more diverse. In Eq. (10), if the coefficient, $\gamma_{3}$, is significant and negative, this indicates that evidence of herding behavior exists in the downside market as Australian investors would be affected by the bahaviour of other investors, or they may rely on their own sources of information, although of their level of market activity.

\subsection{The asymmetric effect of fundamental factors}

It was argued that stock returns and herding are likely to be affected by fundamental factors at market-level or firm-level (Hwang \& Salmon, 2006; Tan et al., 2008). To control for the effects of fundamentals, the present study adds to the model in Eq. (5) the following factors, namely, the dividend yield (DY), earnings per share (EPS), price-earnings ratio (PE), the bank-accepted bills rate (BAB), and the government bond yield (BD) to the herding regression. If the estimated coefficient, $\gamma_{2}$, is significantly negative, evidence of the tendency of herding will be reported. Goyal and Santa-Clara (2003) reported that there is a potential concern as to whether the herding coefficient, $\gamma_{2}$, captures the relation between idiosyncratic risk and market returns. In order to control for the impact of fundamentals, several lags of the CSAD are included as a control variable into Eq. (11). The $\operatorname{GARCH}(1,1)$ is also specified as follows:

$$
C S A D=\beta_{0}+\beta_{1}\left(R_{m t}\right)+\beta_{2}\left(R_{m t}^{2}\right)+\beta_{3}\left(D Y_{t}\right)+\beta_{4}(E P S)+\beta_{5}\left(P E_{t}\right)+\beta_{6}\left(B D_{t}\right)+\beta_{7}(B A B)+\varepsilon_{t}
$$

While both market-level and firm-level fundamental variables are added to Eq. (7), it is also expected that the coefficient, $\gamma_{2}$, would remain significantly negative to provide further evidence of herd behavior.

\subsection{Asymmetric effects of trading volume}

The issue that the level of herding behavior may be associated with trading volume is examined in the following specification because of the possible incidence of the asymmetric effects during periods of high or low volume. The trading volume is regarded as high if on time $t$ it is greater than the previous 30-day (or 12-month) moving average. While trading volume is regarded as low if it is less than the previous 30-day (or 12-month) moving average. The possible asymmetric effects are examined by using the following empirical specifications:

$$
C S A D_{t}^{V}=\delta_{0}+\delta_{1}^{V}\left|R_{m t}^{V}\right|+\delta_{2}^{V}\left(R_{m t}^{V}\right)^{2}+\varepsilon_{t}
$$




$$
\begin{aligned}
& C S A D_{t}^{\text {VHig }}=\delta_{0}+\delta_{1}^{\text {VHig }}\left|R_{m t}^{\text {VHig }}\right|+\delta_{2}^{\text {VHig }}\left(R_{m t}^{\text {VHig }}\right)^{2}+\varepsilon_{t} \\
& C S A D_{t}^{\text {VLow }}=\delta_{0}+\delta_{1}^{\text {VLow }}\left|R_{m t}^{\text {VLow }}\right|+\delta_{2}^{\text {VLow }}\left(R_{m t}^{\text {VLow }}\right)^{2}+\varepsilon_{t}
\end{aligned}
$$

where $\mathrm{V}$ is the return of trading volume of the market index for in period t; the VHig and VLow refer to high and low trading volume, respectively. In the high volume, if the coefficient, $\gamma_{2}$, is significantly negative, it would suggest herding in these markets. In the low volume, if the coefficient, $\gamma_{2}$, is significantly negative, this indicates that there is evidence of herding. In contrast, if the tendency for herding by Australian investors occurs only in the high volume situation, the information driving their behavior may be more diverse during relatively low volume periods.

\subsection{Asymmetric effects of volatility}

The potential asymmetric effect of market volatility on herding behavior is also examined in the study. The volatility is regarded to be high if the observed volatility exceeds its moving average over the previous 30-day (or 12-month) time period. While volatility is regarded as low if it is below the 30-day (12-month) moving average. Therefore, the following equations comprise the models for this effect:

$$
\begin{gathered}
C S A D_{t}=\delta_{0}+\delta_{1}^{\sigma_{t}^{2} V}\left|R_{m t}^{\sigma_{t}^{2} V}\right|+\delta_{2}^{\sigma_{t}^{2} V}\left(R_{m t}^{\sigma_{t}^{2} V}\right)^{2}+\varepsilon_{t} \\
C S A D_{t}=\delta_{0}+\delta_{1}^{\sigma_{t}^{2} V H i g}\left|R_{m t}^{\sigma_{t}^{2} V H i g}\right|+\delta_{2}^{\sigma_{t}^{2} \text { VHig }}\left(R_{m t}^{\sigma_{t}^{2} V H i g}\right)^{2}+\varepsilon_{t} \\
C S A D_{t}=\delta_{0}+\delta_{1}^{\sigma_{t}^{2} V \text { Vow }}\left|R_{m t}^{\sigma_{t}^{2} \text { VLow }}\right|+\delta_{2}^{\sigma_{t}^{2} \text { VLow }}\left(R_{m t}^{\sigma_{t}^{2} \text { VLow }}\right)^{2}+\varepsilon_{t}
\end{gathered}
$$

where $\sigma_{t}^{2} V$ is the volatility of market return in period t; $\sigma_{t}^{2} V H i g$ and $\sigma_{t}^{2} V L o w$ refer to high return volatility and low return volatility, respectively. $\sigma_{t}^{2}$ is calculated as the variance of the error terms of the regression of the lagged market returns in period t. This variance is computed using the past 30-day or 12-month period. If the estimated coefficient, $\delta_{2}$, significantly negative, evidence of herding is detected. In addition, under conditions of low volatility, if the coefficients, $\delta_{2}$, are significantly negative, this suggests evidence of the presence of herding in the Australian equity market.

\subsection{The effect of cross-market information}

Following Chen et al. (2008) who find bilateral feedback trading between A and B shares of the Chinese equity markets, it is of interest in the present study to examine whether Australian investors make their investment decisions based on other investors' decisions. The relation between return dispersions and cross-market information is tested by adding the squared cross-market return of each of the stock markets indices of the four main industrial countries such as the US, the UK, Japan and China as it appears in the regression as follows:

$$
C A S D_{t}=\gamma_{0}+\gamma_{1} R_{m t}+\gamma_{2}\left(R_{m t}\right)^{2}+\gamma_{3}\left(R_{J P t}\right)^{2}+\gamma_{4}\left(R_{C H t}\right)^{2}+\gamma_{5}\left(R_{U K t}\right)^{2}+\gamma_{6}\left(R_{U S t}\right)^{2}+\varepsilon_{t}
$$

where $R_{\mathrm{JPt}}$ is the returns of the Japanese stock market index; $R_{\mathrm{CHt}}$ refers to the returns of the Chinese stock market index; $\mathrm{R}_{\mathrm{UKt}}$ is the returns of the UK stock market index; $\mathrm{R}_{\mathrm{USt}}$ is the returns of the Chinese stock market index. It is expected that if the coefficient, $\gamma_{2}$, is significantly negative, herding is present as the behavior of Australian investors would be affected by receiving cross-market information. However, if the estimated coefficient, $\gamma_{2}$, is positive, there would be no evidence supporting the notion that the return dispersion decreases as Australian investors are not affected by cross-market information.

\section{Data}

The study concentrates on detecting herding at daily and monthly horizons by employing the largest 251 stock returns included in the two principle indexes of the All Ordinaries Index (AOI) and the S\&P300 index over the period from the beginning of January 2003 to the end of October 2010. The Australian stock market is among the very active exchanges in the world, and does generally exhibit stock price innovations occurring on a high volume basis. All data are sourced from the Australian Stock Exchange (ASX) database. The return from the risk-free rate of interest (2-year Government bond rate) is calculated as the natural logarithm of the equivalent price relatives of each observation, sourced from the quarterly bulletins of the Reserve bank of Australia (RBA). In addition, the Bank-accepted bills rate and the 2-year Government bond yield are also obtained from the RBA 
website. Therefore, the excess returns of all the variables calculated by subtracting the continuously compounding logarithmic risk-free rate of returns from the actual continuously compounding logarithmic returns of actual returns of each variable. The author also receives the financial accounting data from the Thompson Reuters database of the fundamental factors. All data series are stationary as shown by the Dickey-Fuller (DF) test.

\section{Results}

\subsection{Univariate Analysis}

Summary descriptive statistics of herding measures and the variables used in herding models are reported in Table 1 for both daily and monthly basis. The average of monthly stock returns is higher than that for daily returns with higher standard deviations. This indicates that herding phenomenon would exist because monthly dataset has a higher frequency and ranges compared with daily frequency data. The monthly mean values of the CSSD for AOI and S\&P300 are consistently higher than that of daily CSSD for the same indices, accompanied by higher standard deviations. In addition, the Table also shows that for monthly statistics the mean values of the CSAD for both indices are consistently higher than that of daily CSAD for both indices. These results would be true because Australian investors would be better informed and they would have their own analytical tools which allow them to reallocate their investment, leading to higher means, range, values and standard deviations. These statistics are as expected because the value of dispersion measures increases with increase in data frequency.

\section{Insert Table 1 here}

Table 1 also shows that the average and range values of monthly stock indices' returns are higher than that for daily data associated with higher standard deviations. This is due to a number of reasons. The AOI index represents the Australian stock market patterns more efficiently than S\&P300 index. The AOI takes into account all listed stocks compared with the S\&P300 index which represents the largest 300 stocks. The information contained in the AOI would accurately reflect the real image of the Australian market more than the S\&P300. Therefore, AOI returns would have the possibility of fluctuating more than the S\&P300 returns to show evidence of herding.

\subsection{Multivariate Analysis}

\subsubsection{The results of applying the $\mathrm{CH}$ approach}

The results of the analysis of herding when applying the $\mathrm{CH}$ approach are reported in Table 2 . The Table shows no evidence of herd behavior in the Australian equity market in all Panels (A, B, C, and D) for the daily and monthly series of AOI and the S\&P300. For all the extreme criteria used $(1 \%, 5 \%$ and $10 \%)$, the estimated coefficients, $\beta_{1}$ and $\beta_{2}$, are positive and significant suggesting no evidence of herding phenomenon. This indicates that equity return dispersions actually tend to increase rather than to decrease during extreme market conditions. The positive sign of $\beta_{1}$ indicates that the change in investors' behaviors associated with extreme upward price movements has not been captured. This means that an increase in the CSSD measure during days, or months, in extreme upward price movements provides no evidence in favor of herd behavior. Moreover, $\beta_{2}$ is also significant and positive in all the models suggesting no evidence of herding in periods of down price movements. These results are consistent with the results of $\mathrm{CH}$.

\section{Insert Table 2 here}

\subsubsection{Asymmetric effects of market returns applying the CCK approach}

Before reporting the asymmetric results, regression coefficients of the non-linear relationship between CSAD and market return are recorded in Table 3 (as in Eq. 5). It is noted that evidence of nonlinear herding is present for both monthly and daily series of the indices, indicating that beyond a certain threshold point the CSAD may decline when market returns increase. In Table 3, the estimated coefficients of whether Australians exhibit asymmetric herding in terms of the up and down market return are recorded (as in Eqs 6 and 7). For the daily and the monthly AOI index returns, the results suggest that evidence of asymmetric herding is found in periods of a rising market because, $\delta_{2}$, is negative and significant. To illustrate, the general quadratic relationship between CSAD and $\mathrm{R}_{\mathrm{mt}}$ is applied now for the daily up market using Eq. (5). The quadratic relationship suggests that CSAD reaches its maximum value when $R_{m t}=-\left(\alpha_{1} / 2 \alpha_{2}\right)$ reaches its minimum value. Using a 0.03 average value of market return as a threshold of market stress, with $\delta_{1}=2.04$, the CSAD reaches its maximum value of 0.055 if $\alpha_{2}=-7.22$. However, no evidence of linear herding is found in periods of rising markets because, $\delta_{1}$, is positive and significant. 
In periods of a falling market, however, different results of the daily and the monthly AOI are reported in Table 3. In such periods, there is no evidence of asymmetric herding because, $\delta_{2}$, is positive and significant, indicating that Australian investors behave differently to changes in market returns when the market is trending down. For example, when the general quadratic relationship between CSAD and $\mathrm{R}_{\mathrm{mt}}$ is applied using the daily down market as in Eq. (5), CSAD reaches its minimum value when $R_{m t}=-\left(\delta_{1} / 2 \delta_{2}\right)$ reaches its minimum value too. Using a -0.056 average value of market return as a threshold of market stress, with $\alpha_{1}=-4.34$, the CSAD reaches its maximum value of -0.04 if $\delta_{2}=90.0$. However, evidence of linear herding is found in periods of down markets because, $\delta_{1}$, is negative and significant. To interpret, the Australian government policy changes and its interventions are likely to affect the stock market by creating market instability. Because of information asymmetry, less-informed and experienced investors are more concerned about the risk triggered by government intervention in a down market. For this reason, they are likely to exhibit herding formation in a down market. In terms of daily and monthly series of S\&P300 returns, similar results are reported as evidence of asymmetric effects of herding appears in periods of the up markets. In addition, evidence of linear herding exists in periods of down markets.

\subsubsection{The asymmetric effect of financial crisis}

The results of whether herding exhibits asymmetric effects in terms of the financial crisis are reported in Table 4 . It is noted that to test for this effect, a dummy variable procedure (see Eqs. 8, 9 and 10) is undertaken to take a value of unity through the period of the crisis from the beginning of January, 2007 until the end of December, 2008 or otherwise zero. This dummy variable is multiplied by the squared value of market returns. For all daily and monthly market returns series (see ALL in Table 4), the estimated coefficients, $\gamma_{3}$, are negative and significant indicating that the Australian herding behavior is significantly affected by the 2008 financial crisis. This means that Australian stock investors exhibit asymmetric herding with respect to the 2008 financial crisis. The inclusion of the dummy variable to the model increases the explanatory power of the nonlinear model (in Eq. 5) in favor of the evidence of asymmetric herding. This result contradicts the findings of Tan et al. (2008) who found that for Shanghai and Shenzhen A and B shares herding behavior was not significantly influenced by the Asian crisis.

\section{Insert Table 4 here}

When testing for herding asymmetric effects in terms of the financial crisis in periods of extreme market conditions, Australian investors generally display strong asymmetric herding characteristics because, $\gamma_{3}$, are negative and significant in monthly and daily series. This evidence suggests that the recent financial crisis have an impact on the Australian herding behavior because the CSAD decrease in periods of stress. In extreme market condition, it is noted that the evidence of asymmetric herding remains active in the up and down markets. However, in the crisis period, evidence of the asymmetric effect in herding is reported only in periods of a falling market, while no evidence of the asymmetric effect in herding is found in periods of a rising market. The results can be explained based on different grounds. One explanation is that, because of the negative impact of crisis, Australian investors continue to herd for protection based on their characteristic preferences or their managerial reputation. For example, better informed investors would push stock price higher than their intrinsic values when they cluster together or herd for protection (Wermers, 1999; Sias, 2004; Jeon \& Moffett, 2010). Market volatility is also the other reason for the influence of the crisis. Investors would herd for protection as prices are pushed beyond their intrinsic values because of uncertainty and risks (Chang \& Dong, 2006; Dasgupta et al., 2011). Shocks in stocks in periods of crisis would have a major impact on a firm's idiosyncratic volatility and confirm herding phenomenon. Therefore, Australian investors would also herd in up and down markets for protection when they buy or sell stocks.

\subsubsection{The effect of fundamental factors}

The results of the effect of fundamentals on the tendency of herding are reported in Table 5. This issue is explained by the argument of Hwang and Salmon (2006) who stated that stock returns and herding are likely to be affected by fundamentals, at market level or firm level. In the estimated models (1 to 5), $\beta_{2}$ is negatively significant. In summary, even after controlling for the effect of market and firm fundamentals, evidence of herd behavior remains visible. A potential concern is whether the herding coefficient, $\beta_{2}$, is capturing the relation between idiosyncratic risk and market returns as documented by Chang and Dong (2006) and Dasgupta et al. (2011). Therefore, although these fundamental variables are significant, $\beta_{2}$ remains negative and significant, suggesting further evidence of herd behavior.

Insert Table 5 here 


\subsubsection{Asymmetric effects of trading volume}

The results of the asymmetric effects on Australian herding with respect to high and low volume states are reported in Table 6 (see Eqs 14, 15 and 16). The evidence for daily data indicates that herding in the Australian stock exchange is present in both high and low volume markets because, $\delta_{2}$, is significant and negative. If herding (CSAD) increases, the trading volume will decrease. This asymmetric effect of herding suggests that it is possible that the same information would drive the behavior of Australian investors during both states. However, the evidence of monthly asymmetric herding has not been captured $\left(\delta_{2}\right.$ is negative but insignificant. Because Australian investors may be affected by foreign investors, they would rely on their own sources of information regardless of their level of market activity. To compare, the negative daily relationship between herding and the trading volume on both low and high suggests that the information driving their behavior may be more diverse than in monthly basis. In addition, the insignificant relationship of monthly data may be associated with measurement errors of the variables and with the frequency and the length of data used.

Insert Table 6 here

\subsubsection{Asymmetric effects of market volatility}

To examine the potential asymmetric effects of herding associated with market volatility, the volatility series of market returns is divided into high volatility and low volatility periods. In Table 7, the results of asymmetric herding in response to market volatility are reported. For the daily series of indices, the coefficient, $\delta_{2}$, for the high and low returns volatility is positive and insignificant, suggesting that there is no evidence of asymmetric herding. For the monthly series, however, under high and low volatility conditions of AOI returns, $\delta_{2}$ is negatively significant only in the high volatility period (see Table 7). This suggests that in the high volatile period evidence of asymmetric herding is captured. Such result corroborates the view that herding phenomenon results in a decrease of the market volatility in periods of high volatility. While, for periods of low volatility, a negative and insignificant coefficient is found. This indicates that no evidence of asymmetric effect is captured within the Australian equity market. Under monthly S\&P300 returns, it is noted that there is no evidence of asymmetric effects on herding in periods of high and low volatility (see $\delta_{2}$ for all periods is significantly positive). These monthly results confirm the findings reported by and Tan et al. (2008) and contradict the finding reported by Hachicha et al. (2007).

\section{Insert Table 7 here \\ Insert Table 8 here}

\subsubsection{The effect of cross-market information}

To examine whether Australian investors make their investment decisions based on other worldwide investors' decisions, the current study tests for the effects of the cross-market information on the tendency of herding by adding the squared foreign market returns of the US, the UK, Japan and China (see Eq. 18). In Table 8, for the daily series of AOI and S\&P300, it is noted that $\gamma_{2}$ is negative and significant suggesting that the cross-market information impacts herding. In fact, model (1) reports that the daily coefficients, $\gamma_{5}$ and $\gamma_{6}$, representing the returns from the UK and the US indices are significant and negative. This confirms the view that Australian investors are affected by the behaviors of their foreign counterparts in the UK and the US. In Models (2 -5), evidence of the effect of these foreign returns on the Australian herding is noticed from market returns of the UK and the US as well as China. For monthly series, evidence of Australians herding is also reported (as $\gamma_{2}$ shows). The effect of the cross-market information on the tendency of Australian herding is also found only for China and the US.

\section{Conclusion}

The current paper has examined the existence of herd behavior in the Australian stock market. Results based on daily and monthly data show mixed evidence of the detection of herding. When the $\mathrm{CH}$ method is used lack of power in reporting evidence of herd behavior is found for both the AOI index and the S\&P300 index on the extreme market stress. However, when applying CCK, evidence of herding over daily and monthly time periods, is indeed present, suggesting that herding phenomenon exists in the up and the down markets. Moreover, the evidence of herding is found to be stronger during periods of rising markets. One interesting aspect of this study is the identification of threshold market returns above which herd behavior is more likely to occur within the 2008 financial crisis. It is found that the asymmetric effect of the financial crisis on herding is influential and the evidence of herding remains active.

Other motivating features noticed in this paper are the asymmetric herding caused by fundamentals, the trading volume, and the volatility of market returns, on the Australian herd behavior. The results show that Australian 
investors would not be affected by fundamental variables neither when using firm-level nor market-level variables. This is because there is no evidence for the negative relationship between CSAD and these variables. However, evidence of the asymmetric effect of herding in terms of trading volume, on daily basis for both indices is found, suggesting that herding exists in the high volume state, while the evidence is not captured in the low volume state. Under monthly basis, although the relationship between trading volume in the high and low states and herding is negative, the evidence of the asymmetric effect is not captured. This is because Australian investors may have their own sources of information regardless of the level of market activity. The evidence of the asymmetric herding created by market volatility is difficult to capture. Evidence of the effect of asymmetric on the Australian herd behavior is not captured under daily basis for both stock indices. Under monthly, evidence of the asymmetric effect is reported only for the high volatility period of the AOI returns, suggesting that investors tend to herd in periods of high volatility. While for the low volatility state, no evidence of this effect is captured. However, the results are different for the S\&P300 returns indicating no evidence of this effect in both high and low volatility states.

The last major findings of this study are related to the effects of investors in foreign stock markets on the tendency of herding of the Australian investors. It is reported that, for daily data, Australian investors have a tendency of herding and are affected by the decisions of foreign investors of the US, the UK and China. While there is no effect of Japanese investors on the Australian herding tendency. However, on monthly basis, Australian investors only affected by the investment behaviors of the US and the UK investors. A possible future research effort could be applied through using a quantile regression instead of least square estimation. Since the Australian equity market has a high percentage of foreign shareholders, this study can be applied on the foreign institutional ownership to detect for herding.

\section{References}

Ang, A., Hodrick, R. J., Xing, Y., \& Zhang. X. (2006). The cross-section of volatility and expected returns. Journal of Finance, 61 (1). 259-299. http://dx.doi.org/10.1111/j.1540-6261.2006.00836.x

Ali, P U., Stepledon, G., \& Gold, M. (2003). Corporate Governance and Investment Fiduciaries. Thomson Legal \& Regulatory, (April). [Online] Available: http://papers.ssrn.com/sol3/papers.cfm?abstract_id=395261

Banerjee, A., \& Drew, F. (2009). Word-of-mouth learning. Games and Economic Behavior, 46 (1), 1-22. http://dx.doi.org/10.1016/S0899-8256(03)00048-4

Barber, B. M., Terrance, O., \& Zhu, N. (2004). Systematic noise. Journal of Financial Markets, 12 (4), 547-69. http://dx.doi.org/10.1016/j.finmar.2009.03.003

Bikhchandani, S., Hirshleifer, D., \& Welch, I. (1992). A theory of fads, fashion, custom, and cultural change as informational cascades. Journal of Political Economy, 100 (5), 992-1026. http://dx.doi.org/10.1086/261849

Boyson, N. M. (2010). Implicit incentives and reputational herding by hedge fund managers. Journal of Empirical Finance, 17 (3), 283-299. http://dx.doi.org/10.1016/j.jempfin.2009.10.005

Pink, B. (2011). Managed Funds. The Australian Bureau of Statistics, No. 5655.0, (September quarter). [Online] Available: http://www.abs.gov.au/ausstats/abs@.nsf $/ \mathrm{mf} / 5655.0$

Cajueiro, D. O., \& Tabak, B. M. (2009). Multifractality and herding behavior in the Japanese stock market. Chaos Solitons Fractals, 40 (1), 497-504. http://dx.doi.org/10.1016/j.chaos.2007.07.091

Campbell, J. Y., Grossman, S. J., \& Wang, J. (1993). Trading Volume and Serial Correlation in Stock Returns. Quarterly Journal of Economics, 108 (4), 905-39. http://dx.doi.org/10.2307/2118454

Campbell, J. Y., Lettau, M., Malkiel, B. G., \& Xu, Y. (2001). Have individual stocks become more volatile? An empirical exploration of idiosyncratic risk. Journal of Finance, 56 (1), 1-43. http://dx.doi.org/10.1111/0022-1082.00318

Campbell, J. Y., Ramadorai, T., \& Schwartz, A. (2009). Caught on tape: Institutional trading, stock returns, and earnings announcements. Journal of Financial Economics, 92 (1), 66-91. http://dx.doi.org/10.1016/j.jfineco.2008.03.006

Caparrelli, F., D'Arcangelis, A. M., \& Cassuto, A. (2004). Herding in the Italian Stock Market: A Case of Behavioral Finance. Journal of Behavioral Finance, 5 (4), 222 - 30. http://dx.doi.org/10.1207/s15427579jpfm0504_5

Chang, C. (2010). Herding and the role of foreign institutions in emerging equity markets. Pacific-Basin Finance Journal, 18 (2), 175-85. http://dx.doi.org/10.1016/j.pacfin.2009.11.001 
Chang, E. C., Cheng, J. W., \& Khorana, A. (2000). An examination of herd behavior in equity markets: An international perspective. Journal of Banking and Finance, 24 (10), 1651-79. http://dx.doi.org/10.1016/S0378-4266(99)00096-5

Chang, E. C., Cheng, J. W., \& Pinegar, J. M. (1999). Does futures trading increase stock market volatility? The case of the Nikkei stock index futures markets. Journal of Banking and Finance, 23 (5), 727-53. http://dx.doi.org/10.1016/S0378-4266(98)00069-7

Chang, E. C., \& Dong, S. (2006). Idiosyncratic volatility, fundamentals, and institutional herding: Evidence from the Japanese stock market. Pacific-Basin Finance Journal, 14 (2), 135-54. http://dx.doi.org/10.1016/j.pacfin.2005.09.001

Chen, Y., Wang, C., \& F. Lin. (2008). Do Qualified Foreign Institutional Investors Herd in Taiwan's Securities Market?. Emerging Markets Finance and Trade, 44 (4), 62-75. http://dx.doi.org/10.2753/REE1540-496X440405

Chiang, T. C., Li, J., \& Tan, L. (2010). Empirical investigation of herding behavior in Chinese stock markets: Evidence from quantile regression analysis. Global Finance Journal, 21 (1), 111-24. http://dx.doi.org/10.1016/j.gfj.2010.03.005

Chiang, T. C., \& Zheng, D. (2010). An empirical analysis of herd behavior in global stock markets. Journal of Banking and Finance, 34 (8). 1911-21. http://dx.doi.org/10.1016/j.jbankfin.2009.12.014

Choe, H., Kho, B-C., \& Stulz, R. M. (1999). Do foreign investors destabilize stock markets? The Korean experience in 1997. Journal Financial Economics, $54 \quad$ (2), 227-64. http://dx.doi.org/10.1016/S0304-405X(99)00037-9

Choi, N., \& Sias, R. W. (2009). Institutional industry herding. Journal of Financial Economics, 94 (3), 469-91. http://dx.doi.org/10.1016/j.jfineco.2008.12.009

Chow, G. C. (1960). Tests of Equality between Sets of Coefficients in Tow Linear Regressions. Econometrica, 28 (2). 591-603. [Online] Available: http://www.jstor.org/stable/1913018

Christie, W., \& Huang, R. (1995). Following the pied piper: do individual returns herd around the market? Financial Analysis Journal, 51 (4), 31-37. http://dx.doi.org/10.2469/faj.v51.n4.1918

D'Aloisio, T. (2005). ASX: an important part of Australia's capital markets. Paper presented at the Australian Shareholders' Association Conference, July 13, in Sydney, Australia.

Dasgupta, A., Prat, A., \& Verardo, M. (2011). The Price Impact of Institutional Herding. Review of Financial Studies, 24 (3), 892-925. http://dx.doi.org/10.1093/rfs/hhq137

Demirer, R., \& Kutan, A. M. (2006). Does herding behavior exist in Chinese stock markets?. Journal of International Financial Markets, Institutions and Money, 16 (2), 123-142. http://dx.doi.org/10.1016/j.intfin.2005.01.002.

Demirer, R., Kutan, A. M., \& Chen, C-D. (2010). Do investors herd in emerging stock markets? Evidence from the Taiwanese market. Journal of Economic Behavior and Organizations, 76 (2), 283-295. http://dx.doi.org/10.1016/j.jebo.2010.06.013

Devenow, A., \& Welch, I. (1996). Rational herding in financial economics. European Economic Review, 40 (3-5), 603-15. http://dx.doi.org/10.1016/0014-2921(95)00073-9

Dickey, D. A., \& Fuller, W. A. (1979). Distribution of the estimators for autoregressive time series with a unit root. Journal of American Statistical Association, 74 (366), 427-31. http://dx.doi.org/10.2307/2286348

Duong, H. N., Kalev, P. S., \& Krishnamurti, C. (2009). Order aggressiveness of institutional and individual investors. Pacific-Basin Finance Journal, 17 (1), 533-546. http://dx.doi.org/10.1016/j.pacfin.2009.05.001

Economou, F., Kostakis, A., \& Philippas, N. (2011). Cross-country effects in herding behavior: Evidence from four south European markets. Journal of International Financial Markets, Institutions \& Money, 21 (3), 443-460. http://dx.doi.org/10.1016/j.intfin.2011.01.005

$\mathrm{Fu}, \mathrm{T}$. (2010). Herding in China Equity Market. International Journal of Economics and Finance, 2 (2), 148-156. http://dx.doi.org/10.5539/ijef.v2n2P148

Gleason, K. C., Mathur, I., \& Peterson, M. A. (2004). Analysis of intraday herding behavior among the sector ETFs. Journal of Empirical Finance, 11 (5), 681-94. http://dx.doi.org/10.1016/j.jempfin.2003.06.003

Grinblatt, M., Titman, S., \& R. Wermers. (1995). Momentum Investment Strategies, Portfolio Performance, and Herding: A Study of Mutual Fund Behavior. American Economic Review, 85 (5), 1088-1105. [Online] Available: 
http://www.jstor.org/stable/2950976

Goyal, A., \& Santa-Clara, P. (2003). Idiosyncratic RiskMatters!. The Journal of Finance, 58 (3), 975-1007. http://dx.doi.org/10.1111/1540-6261.00555

Gu, C. (2010). Herding and bank runs. Journal of Economic Theory, 146 (1), 163-188. http://dx.doi.org/10.1016/j.jet.2010.06.001

Hachicha, N., Bouri, A., \& Chakroun, H. (2007). The Herding Behavior and the Measurement Problems: Proposition of Dynamic Measure. Journal of Business and Policy Research, 3 (2), 160-177. [Online] Available: http://www.wbiaus.org/Hachicha,N.pdf

Henker, J., Henker, T., \& Mitsios, A. (2006). Do investors herd intraday in Australian equities?. International Journal of Managerial Finance, 2 (3), 196-219. http://dx.doi.org/10.1108/17439130610676475

Hung, W., Lu, C-C., \& Lee, C. F. (2010). Mutual fund herding its impact on stock returns: Evidence from the Taiwan stock market. Pacific-Basin Finance Journal, 18(5), 477-93. http://dx.doi.org/10.1016/j.pacfin.2010.06.001

Hwang, S., \& Salmon. M. (2004). Market stress and herding. Journal of Empirical Finance, 11 (4), 585-616. http://dx.doi.org/10.1016/j.jempfin.2004.04.003

Jeon, J. Q., \& Moffett. C. M. (2010). Herding by foreign investors and emerging market equity returns: Evidence from Korea. International Review of Economics and Finance, 19 (4), 698-710. http://dx.doi.org/10.1016/j.iref.2010.03.001

Kim, W., \& Wei, S-J. (2002). Foreign portfolio investors before and during a crisis. Journal of International Economics, 56 (1), 77-96. http://dx.doi.org/10.1016/S0022-1996(01)00109-X

Lakonishok, J., Shleifer, A., \& Vishny, R. W. (1992). The impact of institutional trading on stock prices. Journal of Finance Economics, 32 (1), 23-43. http://dx.doi.org/10.1016/0304-405X(92)90023-Q

Lee, B-S., \& Rui, O. M. (2002). The Dynamic Relationship between Stock returns and Trading Volume: Domestic and cross-country evidence. Journal of Banking and Finance, 26 (1), 51-78. http://dx.doi.org/10.1016/S0378-4266(00)00173-4

Li, W., \& Wang, S. S. (2010). Daily institutional trades and stock price volatility in a retail investor dominated emerging market. Journal of Financial Markets, 13 (4), 448-74. http://dx.doi.org/10.1016/j.finmar.2010.07.003

Liao, T-L., Huang, C-J., \& Wu, C-Y. (2011). Do fund managers herd to counter investor sentiment?. Journal of Business Research, 64 (2), 207 - 212. http://dx.doi.org/10.1016/j.jbusres.2010.01.007

Nofsinger, J. R., \& Sias, R. W. (1999). Herding and feedback trading by institutional and individual investors. Journal of Finance, 54 (6), 2263-95. http://dx.doi.org/10.1111/0022-1082.00188

Scharfstein, D, S., \& Stein, J. C. (1990). Herd behavior and Investment. American Economic Review, 80 (3), 465-479. http://dx.doi.org/10.1257/aer.90.3.705

Shiller, R. J. (1989). Comovements in Stock Prices and Comovements in Dividends. Journal of Finance, 44 (4). 719-29. http://dx.doi.org/10.2307/2328779

Sias, R. W. (2004). Institutional Herding. Review of Financial Studies, 17 (1), 165-206, http://dx.doi.org/10.1093/rfs/hhg035

Tan, L., Chiang, T. C., Mason, J. R., \& Nelling, E. (2008). Herding behavior in Chinese stock markets: An examination of A and B shares. Pacific-Basin Finance Journal, 16 (1-2), 61-77. http://dx.doi.org/10.1016/j.pacfin.2007.04.004

Thaler, R. H. (1999). The End of Behavioral Finance. Financial Analysts Journal, 55 (6), 12-17. http://dx.doi.org/10.2469/faj.v55.n6.2310

Uchida, H., \& Nakagawa, R. (2007). Herd behavior in the Japanese loan market: Evidence from bank panel data. Journal of Financial Intermediations, 16 (4), 555-83. http://dx.doi.org/10.1016/j.jfi.2007.03.007

Venezia, I., Nashikkar, A., \& Shapira, Z. (2011). Firm specific and macro herding by professional and amateur investors and their effects on market volatility. Journal of Banking and Finance, 35 (7), 1599-1609. http://dx.doi.org/10.1016/j.jbankfin.2010.11.015

Walter, A., \& Weber, F. M. (2006). Herding in the German Mutual Fund Industry. European Financial Management, 12 (3), 375-406. http://dx.doi.org/10.1111/j.1354-7798.2006.00325.x 
Wettenhall, R. (2011). Global Financial Crisis: The Australian Experience in International Perspective. Public Organization Review, (1), 77-91. http://dx.doi.org/10.1007/s11115-010-0149-9

Wermers, R. (1999). Mutual Fund Herding and the Impact on Stock Prices. Journal of Finance, 54 (2), $581-622$. http://dx.doi.org/10.1111/0022-1082.00118

Zhou, R. T., \& Lai, R. N. (2009). Herding and information based trading. Journal of Empirical Finance, 16 (3), 388-393. http://dx.doi.org/10.1016/j.jempfin.2009.01.004

Table 1. Descriptive statistics of the variables used in the models of herd behavior - Daily Basis

\begin{tabular}{|c|c|c|c|c|c|c|c|c|c|c|}
\hline \multicolumn{11}{|c|}{ Daily Basis } \\
\hline \multirow[t]{2}{*}{ Items } & \multirow{2}{*}{$\begin{array}{l}\text { No. } \\
\text { Obs }\end{array}$} & \multirow[b]{2}{*}{ Mean } & \multirow[b]{2}{*}{ St Dev. } & \multirow[b]{2}{*}{ Min } & \multirow[b]{2}{*}{ Maxi } & \multicolumn{4}{|c|}{ Serial correlation (rho value) } & \multirow[b]{2}{*}{ DF-test } \\
\hline & & & & & & $\operatorname{AR}(1)$ & $A R(5)$ & $\operatorname{AR}(10)$ & $\operatorname{AR}(20)$ & \\
\hline $\mathbf{R}$ & 1716 & 0.001 & 0.01 & -0.052 & 0.036 & 0.575 & -0.017 & 0.010 & 0.001 & $-22.87 * * *$ \\
\hline CSSD $_{\text {AOI }}$ & 1716 & 0.040 & 0.015 & 0.019 & 0.277 & 0.266 & 0.115 & -0.020 & -0.011 & $-18.56 * * *$ \\
\hline CSSD $_{\mathbf{S \& P 3 0 0}}$ & 1716 & 0.039 & 0.014 & 0.018 & 0.193 & 0.305 & 0.113 & 0.019 & -0.006 & $-17.51 * * *$ \\
\hline CSAD $_{\mathrm{AOI}}$ & 1716 & 0.151 & 0.027 & 0.106 & 0.525 & 0.170 & 0.081 & 0.060 & 0.010 & $-26.31 * * *$ \\
\hline CSAD $_{\text {S\&P300 }}$ & 1716 & 0.148 & 0.024 & 0.105 & 0.286 & 0.046 & -0.012 & -0.063 & -0.016 & $-28.82 * * *$ \\
\hline $\mathbf{R}_{\mathrm{AOI}, \mathrm{t}}$ & 1716 & 0.000 & 0.013 & -0.056 & 0.287 & 0.122 & 0.100 & 0.02 & 0.012 & $-29.37 * * *$ \\
\hline $\mathbf{R}_{\mathrm{S \& P300,t}}$ & 1716 & 0.000 & 0.009 & -0.039 & 0.054 & -0.008 & -0.053 & -0.02 & -0.011 & $-29.61 * * *$ \\
\hline \multicolumn{11}{|c|}{ Monthly Basis } \\
\hline Items & No. & Monn & & Min $>$ & Moxi & \multicolumn{4}{|c|}{ Serial correlation (rho value) } & \\
\hline Vari: & Obs & 17van & • & 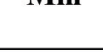 & 17वरा & $\operatorname{AR}(1)$ & $\mathbf{A R}(2)$ & $\operatorname{AR}(5)$ & $\operatorname{AR}(10)$ & DF-test \\
\hline $\mathbf{R}$ & 94 & 0.0076 & 0.0624 & -0.339 & 0.118 & 0.427 & -0.080 & -0.177 & -0.057 & $-5.350 * * *$ \\
\hline $\operatorname{CSSD}_{\mathrm{AOI}}$ & 94 & 0.161 & 0.064 & 0.087 & 0.520 & 0.187 & 0.009 & 0.140 & 0.060 & $-6.453^{* * *}$ \\
\hline CSSD $_{\text {S\&P300 }}$ & 94 & 0.154 & 0.054 & 0.084 & 0.509 & 0.327 & 0.121 & 0.021 & -0.080 & $-4.773 * * *$ \\
\hline $\mathrm{CSAD}_{\mathrm{AOI}}$ & 94 & 0.388 & 0.059 & 0.289 & 0.713 & 0.011 & 0.028 & -0.0003 & -0.0001 & $-4.842 * * *$ \\
\hline CSAD $_{\text {S\&P300 }}$ & 94 & 0.621 & 0.045 & 0.538 & 0.845 & 0.154 & -0.012 & 0.258 & -0.040 & $-6.595^{* * *}$ \\
\hline $\mathbf{R}_{\mathrm{AOI}}$ & 94 & -0.008 & 0.074 & -0.140 & 0.551 & -0.015 & -0.040 & -0.127 & -0.029 & $-6.859 * * *$ \\
\hline $\mathbf{R}_{\text {S\&P300 }}$ & 94 & -0.005 & 0.032 & -0.080 & 0.117 & 0.082 & 0.196 & 0.048 & 0.043 & $-5.534 * * *$ \\
\hline
\end{tabular}


Table 2. The Coefficients of the herding models using the $\mathrm{CH}$ approach

\begin{tabular}{|c|c|c|c|c|c|c|c|c|c|c|c|c|c|}
\hline & \multicolumn{6}{|c|}{$\frac{\text { Panel A: }}{\text { The Coefficients of the CSSD model of herding - Daily Basis }}$} & & \multicolumn{6}{|c|}{ 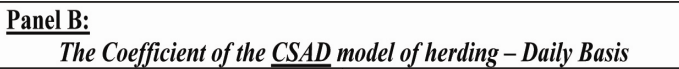 } \\
\hline & \multicolumn{3}{|c|}{ Using AOI (obs. = 1716) } & \multicolumn{3}{|c|}{ Using S\&P300 (obs. = 1716) } & & \multicolumn{3}{|c|}{ Using AOI (obs. = 1716) } & \multicolumn{3}{|c|}{ Using S\&P300 (obs. = 1716) } \\
\hline & $\begin{array}{l}\text { Crit. } \\
=0.01\end{array}$ & $\begin{array}{l}\text { Crit. } \\
=0.05\end{array}$ & $\begin{array}{l}\text { Crit. } \\
=0.10\end{array}$ & $\begin{array}{l}\text { Crit. } \\
=0.01\end{array}$ & $\begin{array}{l}\text { Crit. } \\
=0.05\end{array}$ & $\begin{array}{l}\text { Crit. } \\
=0.10\end{array}$ & & $\begin{array}{l}\text { Crit. } \\
=0.01\end{array}$ & $\begin{array}{l}\text { Crit. } \\
=0.05\end{array}$ & $\begin{array}{l}\text { Crit. } \\
=0.10\end{array}$ & $\begin{array}{l}\text { Crit. } \\
=0.01\end{array}$ & $\begin{array}{l}\text { Crit. } \\
=0.05\end{array}$ & $\begin{array}{l}\text { Crit. } \\
=0.10\end{array}$ \\
\hline$a_{0}$ & $0.149 * * *$ & & & & & & $a_{0}$ & $* * *$ & & & & & \\
\hline & 5) & $(10$ & $(8$ & $(2$ & $(1$ & & & & & & & & \\
\hline$\beta_{1}$ & $0.062 * * *$ & & & & & & $\delta_{1}$ & & & & & & \\
\hline & $(3.08)$ & $(2.75)$ & $(3.17)$ & $(2.5$ & & (2. & & & 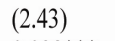 & & & & \\
\hline$\beta_{2}$ & 0. & 0.02 & 0. & 0. & & & $\delta_{2}$ & & & & & & * \\
\hline & & 0 & & & & & & & & & & & \\
\hline & * & & & & & & & & & & & & \\
\hline \multirow[t]{4}{*}{$\mathbf{R}^{2}$} & 0.130 & 0.121 & 0.087 & 0.16 & 0.16 & 0.14 & & 0.138 & 0.18 & 0.14 & 0.1 & 0.1 & 0.1 \\
\hline & \multicolumn{6}{|c|}{$\begin{array}{l}\frac{\text { Panel C: }}{\text { The Coefficients of the CSSD model of herding - Monthly Basis }} \\
\text {. }\end{array}$} & & \multicolumn{6}{|c|}{$\begin{array}{l}\text { Panel D: } \\
\text { The Coefficient of the CSAD model of herding - Monthly Basis }\end{array}$} \\
\hline & \multicolumn{3}{|c|}{ Using AOI (obs. = 94) } & \multicolumn{3}{|c|}{ Using S\&P300 (obs. = 94) } & & \multicolumn{3}{|c|}{ Using AOI (obs. = 94) } & \multicolumn{3}{|c|}{ Using S\&P300 (obs. = 94) } \\
\hline & $\begin{array}{l}\text { Crit. } \\
=0.01\end{array}$ & $\begin{array}{l}\text { Crit. } \\
=0.05\end{array}$ & Crit. & $\begin{array}{l}\text { Crit. } \\
=0.01\end{array}$ & Crit. & Crit. & & $\begin{array}{l}\text { Crit. }= \\
0.01\end{array}$ & $\begin{array}{l}\text { Crit. }= \\
0.05\end{array}$ & $\begin{array}{l}\text { Crit. }= \\
0.10\end{array}$ & $\begin{array}{l}\text { Crit. }= \\
0.01\end{array}$ & $\begin{array}{l}\text { Crit. }= \\
0.05\end{array}$ & $\begin{array}{l}\text { Crit. }= \\
0.10\end{array}$ \\
\hline$\alpha_{0}$ & \begin{tabular}{|l|}
$0.040^{* * *}$ \\
$(106.86)$
\end{tabular} & $\begin{array}{l}0.040^{* * *} \\
(100.95)\end{array}$ & $\begin{array}{l}0.039^{* * *} \\
(94.65)\end{array}$ & $\begin{array}{l}0.039 * * * \\
(1131)\end{array}$ & $0.039^{* * *}$ & & $a_{0}$ & & $\begin{array}{l}0.149 * * * \\
(226.70)\end{array}$ & & & & \\
\hline$\beta_{1}$ & $0.007^{* *}$ & $0.002 * *$ & $0.001^{* *}$ & $0.013^{\prime}$ & 0.00 & 0.0 & $\delta_{1}$ & $* * *$ & 0.01 & $* * *$ & 0.0 & $* * *$ & $2 * *$ \\
\hline & & $(188-5$ & & & & & & & & & & & \\
\hline$\beta_{2}$ & $0.029 * * *$ & $0.009 * * *$ & $0.005^{* * *}$ & $0.004^{*}$ & $0.001 * *$ & $0.000^{* *}$ & $\delta_{2}$ & $2 * * *$ & $0.029^{* * *}$ & $0.018^{* * *}$ & $0.030^{* * *}$ & $0.017 * * *$ & $0.012 * * *$ \\
\hline & $0.000 * * *$ & $0.000^{*}$ & 0.000 & 0.007 & 0.00 & & & $0.000 * * *$ & $0.000^{* * *}$ & $0.000 * * *$ & & $0.000 * * *$ & $0.000^{* * *}$ \\
\hline & 0.138 & 0.117 & 0.189 & 0.165 & $(0.151$ & $(0.122$ & & 0.106 & 0.163 & 0.145 & 0.134 & 0.144 & 0.142 \\
\hline & & & & & & & & & & & & & \\
\hline
\end{tabular}


Table 3. The Coefficients of the CSAD model of herding using the CCK approach

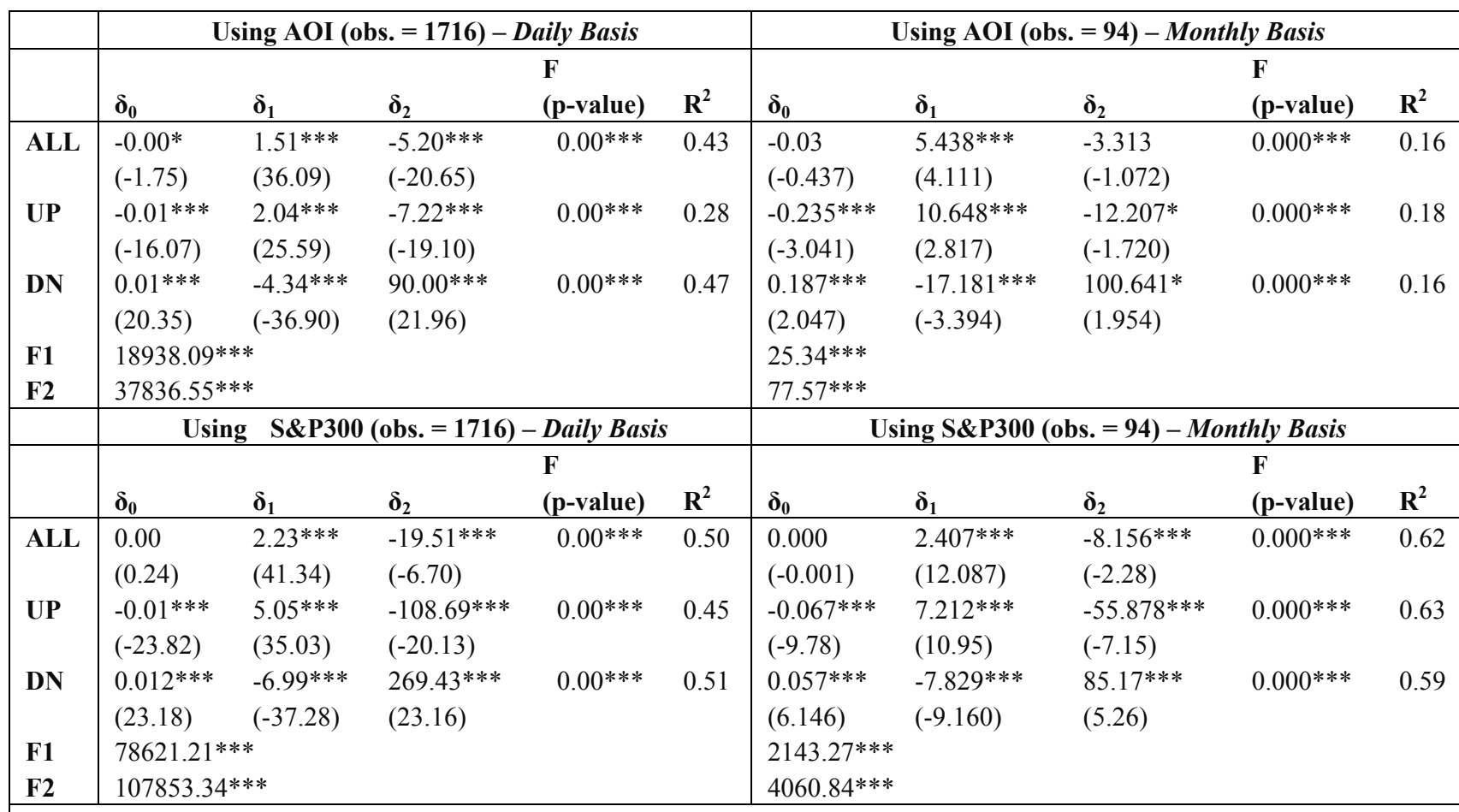

This Table reports the estimated coefficients of the non-linear regression models in Eqs. (5, 6 and 7) for both market indices over daily and monthly intervals. ALL means that the regression model in Eq. (5) is estimated for market returns. UP refers to the regression estimated in Eq. (6) for the up market period (only positive observations of market returns) and the DN stands for the estimated regression in Eq. (7) for the down market period (only negative observations of market returns). Recall, $\delta_{1}$ and $\delta_{2}$ are the linear herding coefficient and the nonlinear herding coefficient, respectively. The confidence parentheses are based on as follows: $(1 \%, 5 \%$, and $10 \%)$ mean $(* * *, * *$, and $*)$, respectively. F1 and F2 statistics are for testing the null hypotheses: $\mathrm{H}_{0}: \delta_{1}{ }^{\mathrm{UP}}=\delta_{1}{ }^{\mathrm{DN}}=0$, and $\mathrm{H}_{0}: \delta_{2}{ }^{\mathrm{UP}}=\delta_{2}{ }^{\mathrm{DN}}=0$, respectively, using Chow (1960) test procedure.

Table 4. The Coefficients of the effects of financial crisis on the tendency of herding

\begin{tabular}{|c|c|c|c|c|c|c|c|c|c|c|c|c|}
\hline & \multicolumn{6}{|c|}{ Using AOI (obs. = 1716) - Daily Basis } & \multicolumn{6}{|c|}{ Using AOI (obs. = 94) - Monthly Basis } \\
\hline & $\gamma_{0}$ & $\gamma_{1}$ & $\gamma_{2}$ & $\gamma_{3}$ & $F$ (p-val.) & $\mathbf{R}^{2}$ & $\gamma_{0}$ & $\gamma_{1}$ & $\gamma_{2}$ & $\gamma_{3}$ & F (p-val.) & $\mathrm{R}^{2}$ \\
\hline ALL & $\begin{array}{l}-0.001 \\
(-1.627)\end{array}$ & $\begin{array}{l}1.509 * * * \\
(36.07)\end{array}$ & $\begin{array}{l}-5.194 * * * \\
(-20.63)\end{array}$ & $\begin{array}{l}-1.241^{*} \\
(-0.227)\end{array}$ & 0.000 & 0.43 & $\begin{array}{l}-0.047 \\
(-0.695)\end{array}$ & $\begin{array}{l}6.813^{* * * *} \\
(4.457)\end{array}$ & $\begin{array}{l}-5.895 * * \\
(-1.735)\end{array}$ & $\begin{array}{l}-50.00^{*} \\
(-1.739)\end{array}$ & 0.000 & 0.23 \\
\hline UP & \begin{tabular}{|l|}
$0.022 * * *$ \\
$(63.79)$ \\
\end{tabular} & $\begin{array}{l}-0.169^{* * * *} \\
(-4.353) \\
\end{array}$ & $\begin{array}{l}0.546^{* * * *} \\
(3.322) \\
\end{array}$ & $\begin{array}{l}21.80 * * * \\
(6.371) \\
\end{array}$ & 0.000 & 0.11 & $\begin{array}{l}-0.053 \\
(-0.956) \\
\end{array}$ & $\begin{array}{l}8.405^{* * *} \\
(4.171) \\
\end{array}$ & $\begin{array}{l}-8.673^{* * *} \\
(-2.418) \\
\end{array}$ & $\begin{array}{l}-60.87^{*} \\
(-1.689)\end{array}$ & 0.000 & 0.74 \\
\hline DN & $\begin{array}{l}-0.022 * * * \\
(-47.36)\end{array}$ & $\begin{array}{l}-0.168^{* *} \\
(-2.109)\end{array}$ & $\begin{array}{l}-1.625 \\
(-0.745)\end{array}$ & $\begin{array}{l}-19.385 * * * \\
(-5.001)\end{array}$ & 0.000 & 0.20 & $\begin{array}{l}-0.35^{* * *} \\
(-2.903)\end{array}$ & $\begin{array}{l}-26.75^{* * *} \\
(-6.295)\end{array}$ & $\begin{array}{l}-387.74 * * * \\
(-11.245)\end{array}$ & $\begin{array}{l}-188.3^{*} \\
(-1.784)\end{array}$ & 0.000 & 0.85 \\
\hline F1 & 493.36 & & & & & & 10.96 & & & & & \\
\hline F2 & 465.70 & & & & & & 22.63 & & & & & \\
\hline \multirow[t]{3}{*}{ F3 } & 469.95 & & & & & & 22.86 & & & & & \\
\hline & \multicolumn{6}{|c|}{ Using S\&P300 (obs. = 1716) - Daily Basis } & \multicolumn{6}{|c|}{ Using S\&P300 (obs. = 94) - Monthly Basis } \\
\hline & $\gamma_{0}$ & $\gamma_{1}$ & $\gamma_{2}$ & $\gamma_{3}$ & F (p-val.) & $\mathbf{R}^{2}$ & $\gamma_{0}$ & $\gamma_{1}$ & $\gamma_{2}$ & $\gamma_{3}$ & F (p-val.) & $\mathbf{R}^{2}$ \\
\hline ALL & $\begin{array}{l}0.000 \\
(0.228)\end{array}$ & $\begin{array}{l}2.230^{* * *} \\
(41.32)\end{array}$ & $\begin{array}{l}-18.44 * * * \\
(-5.176)\end{array}$ & $\begin{array}{l}-2.872 \\
(-0.523)\end{array}$ & 0.000 & 0.50 & $\begin{array}{l}-0.0001 \\
(-0.014)\end{array}$ & $\begin{array}{l}2.399 * * * \\
(12.05)\end{array}$ & $\begin{array}{l}-10.301 * * * \\
(-2.515)\end{array}$ & $\begin{array}{l}-6.475^{*} \\
(-1.972)\end{array}$ & 0.000 & 0.64 \\
\hline UP & $\begin{array}{l}0.017 * * * \\
(41.66)\end{array}$ & $\begin{array}{l}0.382^{*} \\
(1.897)\end{array}$ & $\begin{array}{l}39.66 * * * \\
(2.706)\end{array}$ & $\begin{array}{l}126.72 * * * \\
(11.62)\end{array}$ & 0.000 & 0.49 & $\begin{array}{l}0.062 * * * \\
(33.56)\end{array}$ & $\begin{array}{l}0.934 * * * \\
(7.825)\end{array}$ & $\begin{array}{l}5.575^{* * *} \\
(5.119)\end{array}$ & $\begin{array}{l}-4.65^{* * * *} \\
(-3.319)\end{array}$ & 0.000 & 0.98 \\
\hline DN & $\begin{array}{l}-0.021 * * * \\
(-43.65)\end{array}$ & $\begin{array}{l}-0.007 \\
(-0.054)\end{array}$ & $\begin{array}{l}4.019 \\
(0.577)\end{array}$ & $\begin{array}{l}-10.94 * * * \\
(-2.036)\end{array}$ & 0.000 & 0.42 & $\begin{array}{l}-0.06^{* * *} \\
(-19.63)\end{array}$ & $\begin{array}{l}1.010^{* * *} \\
(5.810)\end{array}$ & $\begin{array}{l}-6.101 * * * \\
(-2.552)\end{array}$ & $\begin{array}{l}-0.057^{*} \\
(-1.703)\end{array}$ & 0.000 & 0.91 \\
\hline F1 & 485.73 & & & & & & 18.10 & & & & & \\
\hline F2 & 483.84 & & & & & & 18.50 & & & & & \\
\hline F3 & 493.29 & & & & & & 18.75 & & & & & \\
\hline $\begin{array}{l}\text { This } \\
\text { UP } \\
\text { (onl } \\
\text { nonl } \\
\text { and }\end{array}$ & $\begin{array}{l}\text { reports } t \\
\text { to the es } \\
\text { ative obs } \\
\text { herding, } \\
\text { spectivel }\end{array}$ & $\begin{array}{l}\text { imated cc } \\
\text { on the up } \\
\text { ons of ma } \\
\text { is for th } \\
\text { F2 and F }\end{array}$ & $\begin{array}{l}\text { cients of th } \\
\text { ket period } \\
\text { returns). } \\
\text { eect of fina } \\
\text { atistics tes }\end{array}$ & $\begin{array}{l}\text { nodels state } \\
\text { ly positive } \\
\text { coefficien } \\
\text { al crisis on } \\
\text { e three nul }\end{array}$ & $\begin{array}{l}\text { in Eqs. (8, } \\
\text { servations } \\
\gamma_{1}, \gamma_{2} \text { and } \gamma \\
\text { e tendency } \\
\text { ypotheses: }\end{array}$ & of $n$ & $\begin{array}{l}\text { Recall, } \\
\text { returns) } \\
\text { e three } \\
\text { ar herdir } \\
\gamma_{1}^{\mathrm{DN}}=0\end{array}$ & $\begin{array}{l}\mathrm{L} \text { means } \mathrm{tl} \\
\mathrm{d} \text { the DN s } \\
\text { lations indi } \\
\text { The confic } \\
\text { and } \mathrm{H}_{0}: \gamma_{2}{ }^{\mathrm{U}}\end{array}$ & $\begin{array}{l}\text { estimation fo } \\
\text { ds for the es } \\
\text { e that } \gamma_{1} \text { is } f \\
\text { ce parenthes } \\
\gamma_{2}{ }^{\mathrm{DN}}=0 \text {, al }\end{array}$ & $\begin{array}{l}1 \%, 5 \\
\mathrm{H}_{0}: \gamma_{3}\end{array}$ & $\begin{array}{l}\text { ons of mar } \\
\text { e down ma } \\
\text { ading, } \gamma_{2} r \\
\text { nd } 10 \% \text { ) } \\
\text { DN }\end{array}$ & returns \\
\hline
\end{tabular}


Table 5. The Coefficients of the effects of fundamental factors on the tendency of herding

\begin{tabular}{|c|c|c|c|c|c|c|c|c|c|c|}
\hline & \multicolumn{5}{|c|}{ Using AOI (obs. = 1716) - Daily Basis } & \multicolumn{5}{|c|}{ Using AOI (obs. = 94) - Monthly Basis } \\
\hline & Model 1 & Model 2 & Model 3 & Model 4 & Model 5 & Model 1 & Model 2 & Model 3 & Model 4 & Model 5 \\
\hline $\mathbf{R}_{\mathrm{mt}}$ & $\begin{array}{l}2.227 * * * \\
(41.25) \\
\end{array}$ & $\begin{array}{l}2.227 * * * \\
(41.27) \\
\end{array}$ & $\begin{array}{l}2.227 * * * \\
(41.29)\end{array}$ & $\begin{array}{l}2.229 * * * \\
(41.30)\end{array}$ & $\begin{array}{l}2.228 * * * \\
(41.30)\end{array}$ & $\begin{array}{l}0.935^{* * *} \\
(4.983)\end{array}$ & $\begin{array}{l}0.932 * * * \\
(5.005) \\
\end{array}$ & $\begin{array}{l}0.931 * * * \\
(5.045)\end{array}$ & $\begin{array}{l}0.950 \text { *** } \\
(5.216)\end{array}$ & $\begin{array}{l}0.950 * * * \\
(5.243) \\
\end{array}$ \\
\hline $\mathbf{R}_{\mathrm{mt}}^{2}$ & $\begin{array}{l}-19.21^{* * * *} \\
(-6.580)\end{array}$ & $\begin{array}{l}-19.32 * * * \\
(-6.629) \\
\end{array}$ & $\begin{array}{l}-19.323^{* * *} \\
(-6.631)\end{array}$ & $\begin{array}{l}-19.41 * * * \\
(-6.658)\end{array}$ & $\begin{array}{l}-19.50^{* * *} \\
(-6.70)\end{array}$ & $\begin{array}{l}-4.991^{*} \\
(-1.704) \\
\end{array}$ & $\begin{array}{l}-5.005^{*} \\
(-1.719) \\
\end{array}$ & $\begin{array}{l}-4.997^{*} \\
(-1.729) \\
\end{array}$ & $\begin{array}{l}-5.228^{*} \\
(-1.827) \\
\end{array}$ & $\begin{array}{l}-5.101^{*} \\
(-1.795) \\
\end{array}$ \\
\hline DY & $\begin{array}{l}0.000 \\
(0.610)\end{array}$ & $\begin{array}{l}0.000 \\
(0.521) \\
\end{array}$ & $\begin{array}{l}0.000 \\
(0.524) \\
\end{array}$ & $\begin{array}{l}0.000 \\
(0.121)\end{array}$ & $\begin{array}{l}0.000 \\
(0.224)\end{array}$ & $\begin{array}{l}0.000 \\
(-0.210)\end{array}$ & $\begin{array}{l}0.000 \\
(-0.163) \\
\end{array}$ & $\begin{array}{l}0.000 \\
(-0.152)\end{array}$ & $\begin{array}{l}0.000 \\
(-0.327) \\
\end{array}$ & $\begin{array}{l}0.000 \\
(-0.426)\end{array}$ \\
\hline EPS & $\begin{array}{l}0.000 \\
(1.582)\end{array}$ & $\begin{array}{l}0.000 \\
(1.185)\end{array}$ & $\begin{array}{l}0.000 \\
(1.190)\end{array}$ & $\begin{array}{l}0.000 \\
(0.713)\end{array}$ & & $\begin{array}{l}0.000 \\
(-0.334)\end{array}$ & $\begin{array}{l}0.000 \\
(-0.327)\end{array}$ & $\begin{array}{l}0.000 \\
(-0.323)\end{array}$ & $\begin{array}{l}0.000 \\
(-0.567)\end{array}$ & \\
\hline PE & $\begin{array}{l}0.000 \\
(1.230) \\
\end{array}$ & $\begin{array}{l}0.000 \\
(1.567) \\
\end{array}$ & $\begin{array}{l}0.000^{*} \\
(1.713)\end{array}$ & & & $\begin{array}{l}0.000 \\
(0.600) \\
\end{array}$ & $\begin{array}{l}0.0003 \\
(0.602) \\
\end{array}$ & $\begin{array}{l}0.0003 \\
(0.710) \\
\end{array}$ & & \\
\hline BD & $\begin{array}{l}-0.047 \\
(-0.570)\end{array}$ & $\begin{array}{l}-0.000 \\
(-0.010)\end{array}$ & & & & $\begin{array}{l}0.154 \\
(0.317)\end{array}$ & $\begin{array}{l}0.0222 \\
(0.088)\end{array}$ & & & \\
\hline BAB & $\begin{array}{l}0.045 \\
(0.659)\end{array}$ & & & & & $\begin{array}{l}-0.126 \\
(-0.318)\end{array}$ & & & & \\
\hline F (p-val.) & 0.000 & 0.000 & 0.000 & 0.000 & 0.000 & 0.000 & 0.000 & 0.000 & 0.000 & 0.000 \\
\hline \multirow[t]{3}{*}{$\mathrm{R}^{2}$} & 0.50 & 0.50 & 0.50 & 0.50 & 0.50 & 0.28 & 0.28 & 0.28 & 0.27 & 0.27 \\
\hline & \multicolumn{5}{|c|}{ Using S\&P300 (obs. = 1716) - Daily Basis } & \multicolumn{5}{|c|}{ Using S\&P300 (obs. = 94) - Monthly Basis } \\
\hline & Model 1 & Model 2 & Model 3 & Model 4 & Model 5 & Model 1 & Model 2 & Model 3 & Model 4 & Model 5 \\
\hline $\mathbf{R}_{\mathrm{mt}}$ & $\begin{array}{l}2.227 * * * \\
(41.25) \\
\end{array}$ & $\begin{array}{l}2.227 * * * \\
(41.274) \\
\end{array}$ & $\begin{array}{l}2.227 * * * \\
(41.29) \\
\end{array}$ & $\begin{array}{l}2.229 * * * \\
(41.30) \\
\end{array}$ & $\begin{array}{l}2.228^{* * * *} \\
(41.30) \\
\end{array}$ & $\begin{array}{l}2.060^{* * * *} \\
(8.318) \\
\end{array}$ & $\begin{array}{l}2.079 * * \\
(8.232) \\
\end{array}$ & $\begin{array}{l}2.084 * * * \\
(8.297) \\
\end{array}$ & $\begin{array}{l}2.079 * * * \\
(8.281) \\
\end{array}$ & $\begin{array}{l}2.080^{* * * *} \\
(8.35) \\
\end{array}$ \\
\hline $\mathbf{R}_{\mathrm{mt}}^{2}$ & $\begin{array}{l}-19.21^{* * * *} \\
(-6.58)\end{array}$ & $\begin{array}{l}-19.32^{* * *} \\
(-6.63)\end{array}$ & $\begin{array}{l}-19.32 * * * \\
(-6.63)\end{array}$ & $\begin{array}{l}-19.41^{* * *} \\
(-6.66)\end{array}$ & $\begin{array}{l}-19.50^{* * * *} \\
(-6.70) \\
\end{array}$ & $\begin{array}{l}-27.32 * * * \\
(-2.651) \\
\end{array}$ & $\begin{array}{l}-30.16^{* * *} \\
(-2.89)\end{array}$ & $\begin{array}{l}-30.81^{* * * *} \\
(-3.00)\end{array}$ & $\begin{array}{l}-30.64 * * * \\
(-2.98) \\
\end{array}$ & $\begin{array}{l}-30.73^{* * *} \\
(-3.02)\end{array}$ \\
\hline DY & $\begin{array}{l}0.000 \\
(0.605)\end{array}$ & $\begin{array}{l}0.000 \\
(0.521)\end{array}$ & $\begin{array}{l}0.000 \\
(0.524)\end{array}$ & $\begin{array}{l}0.000 \\
(0.121) \\
\end{array}$ & $\begin{array}{l}0.000 \\
(0.224) \\
\end{array}$ & $\begin{array}{l}0.000 \\
(0.104)\end{array}$ & $\begin{array}{l}0.000 \\
(0.369) \\
\end{array}$ & $\begin{array}{l}0.000 \\
(0.301)\end{array}$ & $\begin{array}{l}0.000 \\
(0.071)\end{array}$ & $\begin{array}{l}0.000 \\
(0.085) \\
\end{array}$ \\
\hline EPS & $\begin{array}{l}0.000 \\
(1.23)\end{array}$ & $\begin{array}{l}0.000 \\
(1.185)\end{array}$ & $\begin{array}{l}0.000 \\
(1.190) \\
\end{array}$ & $\begin{array}{l}0.000 \\
(0.713)\end{array}$ & & $\begin{array}{l}0.000 \\
(0.402)\end{array}$ & $\begin{array}{l}0.000 \\
(0.427)\end{array}$ & $\begin{array}{l}0.000 \\
(0.381)\end{array}$ & $\begin{array}{l}0.000 \\
(0.090)\end{array}$ & \\
\hline PE & $\begin{array}{l}0.000 \\
(1.582)\end{array}$ & $\begin{array}{l}0.000 \\
(1.567) \\
\end{array}$ & $\begin{array}{l}0.000^{*} \\
(1.713)\end{array}$ & & & $\begin{array}{l}0.000 \\
(1.155)\end{array}$ & $\begin{array}{l}0.0004 \\
(1.103)\end{array}$ & $\begin{array}{l}0.0004 \\
(0.997) \\
\end{array}$ & & \\
\hline BD & $\begin{array}{l}-0.047 \\
(-0.57) \\
\end{array}$ & $\begin{array}{l}-0.000 \\
(-0.010) \\
\end{array}$ & & & & $\begin{array}{l}0.565 \\
(1.45) \\
\end{array}$ & $\begin{array}{l}-0.1021 \\
-0.484 \\
\end{array}$ & & & \\
\hline BAB & $\begin{array}{l}0.045 \\
(0.659) \\
\end{array}$ & & & & & $\begin{array}{l}-0.65 \\
(-2.02) \\
\end{array}$ & & & & \\
\hline F (p-val.) & 0.000 & 0.000 & 0.000 & 0.000 & 0.000 & 0.000 & 0.000 & 0.000 & 0.000 & 0.000 \\
\hline $\mathbf{R}^{2}$ & 0.50 & 0.50 & 0.50 & 0.50 & 0.50 & 0.52 & 0.50 & 0.50 & 0.50 & 0.49 \\
\hline
\end{tabular}


Table 6 . The Coefficients of herding symmetric effects with respect to trading volume

\begin{tabular}{|c|c|c|c|c|c|c|c|c|c|c|}
\hline & \multicolumn{5}{|c|}{ Using AOI (obs. = 1716) - Daily Basis } & \multicolumn{5}{|c|}{ Using AOI (obs. = 94) - Monthly Basis } \\
\hline & $\boldsymbol{\delta}_{0}$ & $\delta_{1}$ & $\delta_{2}$ & $F(p-v)$ & $\mathbf{R}^{2}$ & $\boldsymbol{\delta}_{0}$ & $\delta_{1}$ & $\boldsymbol{\delta}_{2}$ & $F(p-v)$ & $\mathbf{R}^{2}$ \\
\hline $\mathbf{V}$ & $\begin{array}{l}0.136 * * * \\
(4.37)\end{array}$ & $\begin{array}{l}0.002 \\
(0.422)\end{array}$ & $\begin{array}{l}-0.02 * * * \\
(-3.50)\end{array}$ & $0.006^{* * *}$ & 0.15 & $\begin{array}{l}-0.022 * * \\
(-2.160)\end{array}$ & $\begin{array}{l}-0.152 * * * \\
(-2.575)\end{array}$ & $\begin{array}{l}-0.01 \\
(-0.06)\end{array}$ & $0.016^{* *}$ & 0.25 \\
\hline VHig & $\begin{array}{l}0.127 * * * \\
(3.05)\end{array}$ & $\begin{array}{l}-0.004 \\
(-0.404)\end{array}$ & $\begin{array}{l}-0.01 * \\
(-1.96)\end{array}$ & $0.008 * * *$ & 0.12 & $\begin{array}{l}-0.005 \\
(-0.154)\end{array}$ & $\begin{array}{l}-0.048 \\
(-0.185)\end{array}$ & $\begin{array}{l}-0.08 \\
(-0.24)\end{array}$ & $0.023 * *$ & 0.22 \\
\hline VLow & $\begin{array}{l}0.144 * * * \\
(2.98)\end{array}$ & $\begin{array}{l}-0.000 \\
(-0.080)\end{array}$ & $\begin{array}{l}-0.02 * * \\
(-2.16)\end{array}$ & $0.009^{* * *}$ & 0.10 & $\begin{array}{l}0.006 \\
(0.263)\end{array}$ & $\begin{array}{l}-0.859 * * * \\
(-2.32)\end{array}$ & $\begin{array}{l}-2.17 \\
(-1.07)\end{array}$ & $0.05 * *$ & 0.20 \\
\hline F1 & $34.52 * * *$ & & & & & $3.94 * *$ & & & & \\
\hline \multirow[t]{3}{*}{$\mathbf{F} 2$} & $34.86^{* * *}$ & & & & & $3.53 * *$ & & & & \\
\hline & \multicolumn{5}{|c|}{ Using S\&P300 (obs. $=1716)-$ Daily Basis } & \multicolumn{5}{|c|}{ Using S\&P300 (obs. = 94) - Monthly Basis } \\
\hline & $\boldsymbol{\delta}_{0}$ & $\delta_{1}$ & $\boldsymbol{\delta}_{2}$ & $\mathbf{F}(\mathbf{p}-\mathbf{v a})$ & $\mathbf{R}^{2}$ & $\boldsymbol{\delta}_{\mathbf{0}}$ & $\delta_{1}$ & $\boldsymbol{\delta}_{2}$ & $F(p-v)$ & $\mathbf{R}^{2}$ \\
\hline $\mathbf{V}$ & $\begin{array}{l}-0.002 * * * \\
(-3.09)\end{array}$ & $\begin{array}{l}0.002 \\
(1.065)\end{array}$ & $\begin{array}{l}-0.001 * \\
(-1.84)\end{array}$ & $0.000 * * *$ & 0.18 & $\begin{array}{l}-0.089 \\
(-1.24)\end{array}$ & $\begin{array}{l}0.482 \\
(1.34)\end{array}$ & $\begin{array}{l}-0.17 \\
(-0.42)\end{array}$ & $0.06^{*}$ & 0.21 \\
\hline VHig & $\begin{array}{l}-0.002 * * * \\
(-2.55)\end{array}$ & $\begin{array}{l}-0.004 \\
(-1.048)\end{array}$ & $\begin{array}{l}-0.001 * \\
(-1.98)\end{array}$ & $0.012 * *$ & 0.16 & $\begin{array}{l}-0.055 \\
(-0.49)\end{array}$ & $\begin{array}{l}0.34 \\
(0.44)\end{array}$ & $\begin{array}{l}-0.19 \\
(-0.33)\end{array}$ & $0.01 * * *$ & 0.18 \\
\hline VLow & $\begin{array}{l}-0.001 \\
(-1.36)\end{array}$ & $\begin{array}{l}0.002 \\
(0.567)\end{array}$ & $\begin{array}{l}-0.002 * \\
(-1.67)\end{array}$ & $0.030 * * *$ & 0.15 & $\begin{array}{l}-0.001 \\
(-0.02)\end{array}$ & $\begin{array}{l}2.28 \\
(1.23)\end{array}$ & $\begin{array}{l}-2.68 \\
(-1.03)\end{array}$ & $0.03 * *$ & 0.17 \\
\hline F1 & \multicolumn{5}{|l|}{$25.19 * * *$} & \multicolumn{5}{|l|}{$6.41 * * *$} \\
\hline F2 & \multicolumn{5}{|l|}{$26.92 * * *$} & \multicolumn{5}{|l|}{$4.02 * * *$} \\
\hline \multicolumn{11}{|c|}{ 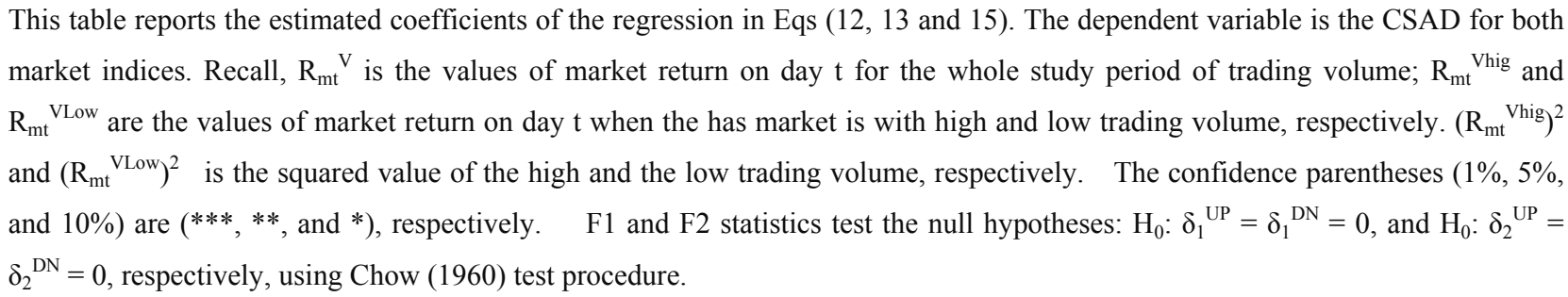 } \\
\hline
\end{tabular}


Table 7. The Coefficients of herding asymmetric effects with respect to market volatility

\begin{tabular}{|c|c|c|c|c|c|c|c|c|c|c|c|c|}
\hline & \multicolumn{6}{|c|}{ Using AOI (obs. = 1716) - Daily Basis } & \multicolumn{6}{|c|}{ Using AOI (obs. = 94) - Monthly Basis } \\
\hline & $\boldsymbol{\delta}_{\mathbf{0}}$ & $\delta_{1}$ & $\boldsymbol{\delta}_{\mathbf{2}}$ & $\begin{array}{l}\text { F } \\
\text { (p-val.) }\end{array}$ & $\mathbf{R}^{2}$ & DW & $\boldsymbol{\delta}_{0}$ & $\delta_{1}$ & $\boldsymbol{\delta}_{2}$ & $\begin{array}{l}\text { F } \\
\text { (p-val.) }\end{array}$ & $\mathbf{R}^{2}$ & DW \\
\hline$\sigma^{2} V$ & $\begin{array}{l}-0.004 \\
(-0.538)\end{array}$ & $\begin{array}{l}-15.45^{* * *} \\
(-2.246)\end{array}$ & $\begin{array}{l}9487.3 \\
(1.525)\end{array}$ & $0.000^{* * *}$ & 0.14 & 2.00 & $\begin{array}{l}-0.183 \\
(-1.382)\end{array}$ & $\begin{array}{l}219.66 \\
(1.275)\end{array}$ & $\begin{array}{l}-33240 . \\
(-1.073)\end{array}$ & $0.018^{* *}$ & 0.11 & 2.00 \\
\hline$\sigma^{2}$ VHig & $\begin{array}{l}0.001 \\
(0.751)\end{array}$ & $\begin{array}{l}-16.91^{*} \\
(-1.873)\end{array}$ & $\begin{array}{l}9867.6 \\
(1.322)\end{array}$ & $0.000^{* * *}$ & 0.12 & 2.00 & $\begin{array}{l}-0.484 * * * \\
(-2.746)\end{array}$ & $\begin{array}{l}442.25^{* * *} \\
(2.676)\end{array}$ & $\begin{array}{l}-7413^{* * *} \\
(-2.804)\end{array}$ & $0.028^{* *}$ & 0.20 & 2.11 \\
\hline$\sigma^{2}$ VLow & $\begin{array}{l}-0.005 \\
(0.011)\end{array}$ & $\begin{array}{l}-21.53 \\
(-1.613)\end{array}$ & $\begin{array}{l}19950 \\
(1.317)\end{array}$ & $0.000 * * *$ & 0.12 & 2.00 & $\begin{array}{l}0.386 \\
(0.182)\end{array}$ & $\begin{array}{l}-179.40 \\
(-0.355)\end{array}$ & $\begin{array}{l}-52384 \\
(-0.280)\end{array}$ & $0.01 * * *$ & 0.32 & 2.52 \\
\hline F1 & \multicolumn{6}{|l|}{$3.13^{* * *}$} & \multicolumn{6}{|l|}{$6.23 * * *$} \\
\hline \multirow[t]{3}{*}{ F2 } & \multicolumn{6}{|l|}{$4.06^{* * *}$} & \multicolumn{6}{|l|}{$6.95^{* * *}$} \\
\hline & \multicolumn{6}{|c|}{ Using S\&P300 (obs. = 1716) - Daily Basis } & \multicolumn{6}{|c|}{ Using S\&P300 (obs. = 94) - Monthly Basis } \\
\hline & $\boldsymbol{\delta}_{\mathbf{0}}$ & $\delta_{1}$ & $\delta_{2}$ & $\begin{array}{l}\text { F } \\
\text { (p-val.) }\end{array}$ & $\mathbf{R}^{2}$ & DW & $\boldsymbol{\delta}_{0}$ & $\delta_{1}$ & $\boldsymbol{\delta}_{2}$ & $\begin{array}{l}\text { F } \\
\text { (p-val.) }\end{array}$ & $\mathbf{R}^{2}$ & DW \\
\hline$\sigma^{2} V$ & $\begin{array}{l}-0.015^{*} \\
(-1.980)\end{array}$ & $\begin{array}{l}-2.865 \\
(-0.426)\end{array}$ & $\begin{array}{l}7872.7 \\
(0.545)\end{array}$ & $0.010^{* * *}$ & 0.13 & 2.00 & $\begin{array}{l}-0.005 \\
(-0.250)\end{array}$ & $\begin{array}{l}-60.54^{* *} \\
(-2.077)\end{array}$ & $\begin{array}{l}18485^{* * *} \\
(2.813)\end{array}$ & $0.00^{* * *}$ & 0.15 & 2.01 \\
\hline$\sigma^{2}$ VHig & $\begin{array}{l}-0.164 \\
(-0.145)\end{array}$ & $\begin{array}{l}-8.975 \\
(-1.024)\end{array}$ & $\begin{array}{l}5562.3 \\
(0.499)\end{array}$ & $0.083 *$ & 0.15 & 2.00 & $\begin{array}{l}0.006 \\
(0.091)\end{array}$ & $\begin{array}{l}-68.44 \\
(-0.970)\end{array}$ & $\begin{array}{l}19590.2 \\
(1.399)\end{array}$ & $0.017^{* *}$ & 0.18 & 2.00 \\
\hline$\sigma^{2}$ VLow & $\begin{array}{l}-0.224 * * \\
(-2.011)\end{array}$ & $\begin{array}{l}-6.166 \\
(-0.441)\end{array}$ & $\begin{array}{l}-16034 \\
(-0.884)\end{array}$ & $0.042 * *$ & 0.11 & 1.99 & $\begin{array}{l}0.0050 \\
(0.225)\end{array}$ & $\begin{array}{l}-99.145^{* *} \\
(-2.113)\end{array}$ & $\begin{array}{l}36346.7^{* * *} \\
(2.157)\end{array}$ & $0.09^{*}$ & 0.10 & 1.99 \\
\hline F1 & \multicolumn{6}{|l|}{$3.02 * *$} & \multicolumn{6}{|l|}{$5.87^{* * *}$} \\
\hline F2 & \multicolumn{6}{|l|}{$3.27 * *$} & \multicolumn{6}{|l|}{$6.30 * * *$} \\
\hline \multicolumn{13}{|c|}{$\begin{array}{l}\text { This table reports the estimated coefficients of the regression in Eqs }(15,16 \text { and } 17) \text {. The dependent variable is the CSAD. } \sigma^{2} \mathrm{~V} \text { is the } \\
\text { variance of the errors of the market return of the whole volatility period; } \sigma^{2} \mathrm{VHig} \text { is the variance of the errors of the market return in the } \\
\text { high volatility period; } \sigma^{2} \text { VLow is the variance of the errors of the market return in the low periods. The confidence parentheses ( } 1 \%, 5 \% \text {, } \\
\text { and } 10 \% \text { ) are }(* * *, * * \text {, and } *) \text {, respectively. F1 and F2 statistics test the null hypotheses: } \mathrm{H}_{0}: \delta_{1}^{\mathrm{UP}}=\delta_{1}^{\mathrm{DN}}=0 \text {, and } \mathrm{H}_{0}: \delta_{2}{ }^{\mathrm{UP}}=\delta_{2}^{\mathrm{DN}}=0 \text {, } \\
\text { respectively, using Chow (1960) test procedure. }\end{array}$} \\
\hline
\end{tabular}


Table 8 . The Coefficients of the effects of exchange-market on the tendency of herding

\begin{tabular}{|c|c|c|c|c|c|c|c|c|c|c|}
\hline & \multicolumn{5}{|c|}{ Using AOI (obs. = 1716) - Daily Basis } & \multicolumn{5}{|c|}{ Using AOI (obs. = 94) - Monthly Basis } \\
\hline & Model 1 & Model 2 & Model 3 & Model 4 & Model 5 & Model 1 & Model 2 & Model 3 & Model 4 & Model 5 \\
\hline $\mathbf{R}_{\mathrm{mt}}$ & $\begin{array}{l}2.384 * * * \\
(25.50)\end{array}$ & $\begin{array}{l}2.41 * * * \\
(25.78)\end{array}$ & $\begin{array}{l}2.43 * * * \\
(26.05)\end{array}$ & $\begin{array}{l}2.40 * * * \\
(26.17)\end{array}$ & $\begin{array}{l}2.43 * * * \\
(26.14)\end{array}$ & $\begin{array}{l}15.38 * * * \\
(2.402)\end{array}$ & $\begin{array}{l}13.12 * \\
(1.904)\end{array}$ & $\begin{array}{l}17.86^{* * *} \\
(2.775)\end{array}$ & $\begin{array}{l}13.25^{*} \\
(1.965)\end{array}$ & $\begin{array}{l}13.35^{*} \\
(1.928)\end{array}$ \\
\hline $\mathbf{R}^{2}{ }_{\mathrm{mt}}$ & $\begin{array}{l}-18.71 * * * \\
(-5.862)\end{array}$ & $\begin{array}{l}-18.43 * * * \\
(-5.716)\end{array}$ & $\begin{array}{l}-18.61 * * * \\
(-5.043)\end{array}$ & $\begin{array}{l}-18.86^{* * *} \\
(-5.814)\end{array}$ & $\begin{array}{l}-19.187 * * * \\
(-5.79)\end{array}$ & $\begin{array}{l}-8.88^{*} \\
(-1.711)\end{array}$ & $\begin{array}{l}-7.71 * \\
(-1.971)\end{array}$ & $\begin{array}{l}-7.356 * * \\
(-2.018)\end{array}$ & $\begin{array}{l}-7.43 * * \\
(-1.867)\end{array}$ & $\begin{array}{l}-7.87 * \\
(-1.962)\end{array}$ \\
\hline $\mathbf{R}_{\mathrm{JPt}}^{2}$ & $\begin{array}{l}0.759 \\
(1.385)\end{array}$ & $\begin{array}{l}0.747 \\
(1.341)\end{array}$ & & & & $\begin{array}{l}3.63 * * \\
(2.22)\end{array}$ & $\begin{array}{l}2.45^{* *} \\
(2.004)\end{array}$ & & & \\
\hline $\mathbf{R}_{\mathrm{CHt}}^{2}$ & $\begin{array}{l}-1.105 \\
(-1.602)\end{array}$ & & $\begin{array}{l}-1.321^{*} \\
(-1.892)\end{array}$ & & & $\begin{array}{l}0.74 * * * \\
(3.36)\end{array}$ & & $\begin{array}{l}0.79 * * * \\
(2.38)\end{array}$ & & \\
\hline $\mathbf{R}^{2}{ }_{\mathrm{UKt}}$ & $\begin{array}{l}-3.64 * * * \\
(-4.121)\end{array}$ & & & $\begin{array}{l}-4.110 * * * \\
(-4.87)\end{array}$ & & $\begin{array}{l}-0.87 \\
(-0.42)\end{array}$ & & & $\begin{array}{l}-18.89 \\
(-0.421)\end{array}$ & \\
\hline $\mathbf{R}_{\text {USt }}^{2}$ & $\begin{array}{l}-0.88^{*} \\
(-1.864)\end{array}$ & & & & $\begin{array}{l}-2.02 * * * \\
(-2.53)\end{array}$ & $\begin{array}{l}-7.70 * * * \\
(-2.27)\end{array}$ & & & & $\begin{array}{l}-5.764 \\
(-0.103)\end{array}$ \\
\hline F (p-val.) & $0.000 * * *$ & $0.000 * * *$ & $0.000 * * *$ & $0.000 * * *$ & $0.000 * * *$ & $0.000 * * *$ & $0.000 * * *$ & $0.000 * * *$ & $0.000 * * *$ & $0.000 * * *$ \\
\hline $\mathbf{R}^{2}$ & 0.52 & 0.50 & 0.50 & 0.52 & 0.51 & 0.46 & 0.18 & 0.33 & 0.19 & 0.18 \\
\hline \multirow[t]{3}{*}{ DW } & 2.01 & 1.89 & 1.88 & 1.912 & 1.91 & 2.18 & 1.93 & 2.11 & 1.99 & 1.96 \\
\hline & \multicolumn{5}{|c|}{ Using S\&P300 (obs. = 1716) - Daily Basis } & \multicolumn{5}{|c|}{ Using S\&P300 (obs. = 94) - Monthly Basis } \\
\hline & Model 1 & Model 2 & Model 3 & Model 4 & Model 5 & Model 1 & Model 2 & Model 3 & Model 4 & Model 5 \\
\hline $\mathbf{R}_{\mathrm{mt}}$ & $\begin{array}{l}2.20 * * * \\
(40.19)\end{array}$ & $\begin{array}{l}2.19 * * * \\
(40.18)\end{array}$ & $\begin{array}{l}2.196 * * * \\
(40.20)\end{array}$ & $\begin{array}{l}2.196 * * * \\
(40.23)\end{array}$ & $\begin{array}{l}2.196 * * * \\
(40.26)\end{array}$ & $\begin{array}{l}2.18^{* * *} \\
(11.39)\end{array}$ & $\begin{array}{l}2.31 * * * \\
(11.92)\end{array}$ & $\begin{array}{l}2.27 * * * \\
(11.11)\end{array}$ & $\begin{array}{l}2.36^{* * *} \\
(11.92)\end{array}$ & $\begin{array}{l}2.284 * * * \\
(12.24)\end{array}$ \\
\hline $\mathbf{R}^{2}{ }_{\mathrm{mt}}$ & $\begin{array}{l}-19.06 * * * \\
(-6.534)\end{array}$ & $\begin{array}{l}-18.89 * * * \\
(-6.47)\end{array}$ & $\begin{array}{l}-18.89 \\
(-6.468)\end{array}$ & $\begin{array}{l}-18.91 * * * \\
(-6.481)\end{array}$ & $\begin{array}{l}-19.02 * * * \\
(-6.520)\end{array}$ & $\begin{array}{l}-7.18 * * * \\
(-2.17)\end{array}$ & $\begin{array}{l}-8.10 * * * \\
(-2.373)\end{array}$ & $\begin{array}{l}-7.33 * * \\
(-2.074)\end{array}$ & $\begin{array}{l}-7.77 * * * \\
(-2.204)\end{array}$ & $\begin{array}{l}-8.01 * * * \\
(-2.432)\end{array}$ \\
\hline $\mathbf{R}_{\mathrm{JPt}}^{2}$ & $\begin{array}{l}0.612 \\
(1.380)\end{array}$ & $\begin{array}{l}0.550 \\
(1.248)\end{array}$ & & & & $\begin{array}{l}-1.50 \\
(-1.06)\end{array}$ & $\begin{array}{l}2.50 * * * \\
(3.493)\end{array}$ & & & \\
\hline $\mathbf{R}^{2}{ }_{\mathrm{CHt}}$ & $\begin{array}{l}0.387 \\
(0.739)\end{array}$ & & $\begin{array}{l}-1.268^{*} \\
(-1.719)\end{array}$ & & & $\begin{array}{l}0.876^{*} \\
(1.963)\end{array}$ & & $\begin{array}{l}1.07 * * * \\
(2.617)\end{array}$ & & \\
\hline $\mathbf{R}_{\mathrm{UKt}}^{2}$ & $\begin{array}{l}-0.774 * * \\
(-2.018)\end{array}$ & & & $\begin{array}{l}-1.172 * \\
(-1.753)\end{array}$ & & $\begin{array}{l}-0.630 \\
(-0.306)\end{array}$ & & & $\begin{array}{l}-14.26 \\
(-0.508)\end{array}$ & \\
\hline $\mathbf{R}_{\text {USt }}^{2}$ & $\begin{array}{l}-1.365^{*} \\
(-1.795)\end{array}$ & & & & $\begin{array}{l}-1.48 * * * \\
(-2.32)\end{array}$ & $\begin{array}{l}-7.28 * * * \\
(-2.756)\end{array}$ & & & & $\begin{array}{l}-5.56 \\
(-0.413)\end{array}$ \\
\hline F (p-val.) & $0.000 * * *$ & $0.000 * * *$ & $0.000 * * *$ & $0.000 * * *$ & $0.000 * * *$ & 0.000 & $0.000 * * *$ & $0.000 * * *$ & $0.000 * * *$ & $0.000 * * *$ \\
\hline $\mathbf{R}^{2}$ & 0.50 & 0.49 & 0.49 & 0.49 & 0.50 & 0.709 & 0.68 & 0.66 & 0.66 & 0.70 \\
\hline DW & 2.03 & 2.03 & 2.02 & 2.03 & 2.02 & 2.002 & 2.23 & 2.16 & 2.36 & 2.16 \\
\hline \multicolumn{11}{|c|}{$\begin{array}{l}\text { This table reports the estimated coefficients of the regression in Eq. (18). The dependent variable is the CSAD. } \mathrm{R}_{\mathrm{mt}} \text { is a proxy for the returns of the } \\
\text { Australian stock market index (AOI and S\&P300); } \mathrm{R}_{\text {mt }}^{2} \text { refers to the squared returns of the Australian stock market index; } \mathrm{R}_{\mathrm{JPt}}^{2} \text { is the squared returns of } \\
\text { the Japanese stock market index; } \mathrm{R}_{\text {CHt }}^{2} \text { is the squared returns of the Chinese stock market index; } \mathrm{R}_{\text {UKt }}^{2} \text { is the squared returns of the UK stock market } \\
\text { index; } \mathrm{R}_{\text {USt }}^{2} \text { is the squared returns of the US stock market index The four foreign indices are: the GSPC-S\&P500 index for the US, the FTSE100 for the } \\
\text { UK, Nikkie } 225 \text { for Japan and the SSE Shanghai Composite Index for China. The confidence parentheses }(1 \%, 5 \% \text {, and } 10 \%) \text { are }(* * *, * * \text {, and } * \text { ), }\end{array}$} \\
\hline
\end{tabular}

